\title{
Határőrizet, rendőrség és humán viszonyok a polgári magyar állam két világháború közötti időszakában \\ DOI : 10.31627/RTF.XXI V.2014.39-40-41-42N.99-118P
}

A magyar rendvédelem történetében jelentős állomás a két világháború közötti Magyar Királyság időszaka. Ekkor váltak egységessé és az egész országra kiterjedővé a magyarországi rendőrségek, azaz a Magyar Királyi Államrendőrség hatósági területe kiterjedt a ország valamennyi városára. Vidéken azonban továbbra is a Magyar Királyi Csendőrség tartotta fenn a rendet, a Magyar Királyi Államrendőrség pedig közvetlen belügyminisztériumi felügyelet, irányítás és ellátás alá került. Az önkormányzati rendőrségek centralizált átszervezését a korabeli terminológia az ,államosítás” névvel jelölte. Az államosítás gyökerei a dualizmus ideéig nyúltak vissza. A Magyar Rendőrtisztviselők Országos Egyesülete keretében indult el az államosítás elméleti előkészítésének a folyamata. A rendőrtisztviselők ugyanis ebben az időben még nem állami, hanem önkormányzati tisztviselők voltak és nem kinevezték, hanem választották őket hat évre, valamint a nyugdíjjogosultságuk jellege is szinte önkormányzatonként eltérő volt. Ebböl a helyzetből akartak a rendőrtisztviselök kitörni a rendőrségek államosítása által. A XX. század elején kedvező időszakban vetették fel a témát, mivel ekkor valósult meg a magyar állam egyik markáns centralizációs folyamata. A rendőrségek államosítását tehát a kormányok pártolóan fogadták. Hasonló volt a helyzet az önkormányzatok részéről is, hiszen oly módon szabadulhattak meg a rendőrségük fenntartásának tetemes költségeitől, hogy nem kellett tartaniuk a települési rendőrség megszünésétől. 1912-ben már az országgyülés elé került a téma. A törvényhozó testület pedig úgy határozott, hogy a Magyar Királyi Belügyminisztériumban külön osztály jöjjön létre a magyarországi rendőrségek államosításának előkészítése érdekében. Az osztály két év alatt tervezetet dolgozott ki, melyet 1914 nyarán beterjesztettek az országgyülés elé, amely azonban a tervezetet átdolgozás céljából visszaküldte. Közben kitört az I. világháború, melynek következtében az államosítás gondolata ismét a háborút követő forradalmak után került előtérbe.

\section{Az államosított magyar rendőrség}

A magyarországi rendőrségek államosítására — igaz már csak a csonka Magyarországon — 1919-ben került sor. Miniszterelnöki rendelet intézkedett a Magyar Királyi Állami Rendőrség létrehozásáról. ${ }^{1} \mathrm{Az}$ államosítás 1919 novemberében kezdődött és 1921 augusztusában fejeződött be. Az átszervezés során a legitimista érzületủ tisztek helyett a HORTHY Miklóshoz hủ szabad királyválasztókat helyezték a rendőrség kulcspozícióiba. A személycseréket általában nyugdíjazás útján valósították meg. Ez nem jelentett tömeges rostálást, a mértéke hasonló volt a proletárdiktatúra időszakára vonatkozó eljárásban felfüggesztett személyekéhez. A proletárdiktatúra idején tanúsított magatartásért 111 személyt függesztettek fel, végül azonban csupán mintegy 50 föt bocsátottak el. Az átszervezést már a felújított vezetés végezte el.

Az 1920. X. 23-ai rendőr díszszemle a Vérmezőn már a kormányzó és a rendőrség közötti kielégítő kapcsolatot demonstrálta. A kormányzó fogadta a rendőrség tisztelgését és kifejezte megelégedését és dicséretét. Novemberben már a rendőrség fegyverezte le a Britanniás-különítményt. Az illetményrendezéssel megállították a legénység kiáramlását a testületből, megkezdődhetett az új struktúra kiépítése. ${ }^{2}$

A Magyar Királyi Állami Rendörség élére — a Magyar Királyi Belügyminisztérium hivatali részlegeként - fökapitányságot szerveztek. Az első országos rendőr-főkapitány 1921. VIII. 16-án foglalta el beosztását. A dicstelen frankhamisítási eset után azonban megszüntették ezt a beosztást. Az ország területét - a városok hatósági területére kiterjedően — fökapitányságokra osztották. A budapesti főkapitányság kiemelt szervezetként működött. A vidéket a kerület rendőr-főkapitányságok fogták össze, ezek alárendeltségébe tartoztak a rendőrkapitányságok és a rendőrkirendeltségek. A rendôr-főkapitányságok székhelye és müködési területe megegyezett a honvéd kerületparancsnokságok és a csendőr-parancsnokságok székhelyeivel és müködési területeivel, de csak a városokra kiterjedően. Az akkori főváros - a mai viszonyainkhoz képest kis-Budapest — agglomerációs körzetére pedig külön szervezeti egységet hoztak létre a Budapest vidéki rendőrkerületet Budapest székhellyel. (I.sz. melléklet)

1931. XII. 31-ei hatállyal kerületi rendőr-fökapitányságokat — a testület elnevezésének Magyar Királyi Rendőrség-re változtatásával - megszüntették, helyükbe 1932. I. 1-től létrehozták a vidéki rendőr-fökapitányságot. Csökkentett hatáskörrel és személyzettel megszervezték viszont a körzeti szemlélő központokat a volt vidéki rendőr-fökapitányságok székhelyén és azok hajdani müködési területére kiterjedő hatállyal. ${ }^{3}$ 
A terület-visszacsatolások nyomán a Magyar Királyságban 2 rendőr-főkapitányság, 9 körzeti szemlélőközpont, 89 rendőrkapitányság és 21 rendőr kirendeltség müködött. ${ }^{4}$

A városi kapitányságok szervezeti felépítése a budapesti kapitányság struktúráját követte, a kisebb városokban azonban egyszerüsödött a rendőrkapitányságok szervezete.

A legkisebb rendőrkapitányságokon is megtalálható volt a közbiztonsági osztály és az igazgatásrendészeti osztály. A kapitányságok szervezetének elengedhetetlen része volt még a detektívtestület, az őrszemélyzeti parancsnokság, a számvevőség, a segédhivatal, a kapitányi hivatal - más néven elnöki osztály — és végül a fogda. A forradalmak után létrehozott új szervezeti egységeket a budapesti rendőrségnél az átszervezés során megszüntették, illetve — funkciójuk meghagyásával - más szervezeti egységek részlegeként, csökkentett létszámmal müködtek tovább. A fökapitánysági különítmény 1919. VIII. 31-töl 1920. VI. 2-áig a politikai pedig 1919. VIII. 8-tól 1920. X. 20-ig müködött. ${ }^{5}$

Az államosított rendőrség budapesti fökapitánysága a kerületi kapitányságokat nem számítva 17 szervezeti egységből állt. A II. világháború időszakáig a budapesti rendőrség struktúrája 3 szervezeti egységgel bővült, a Légoltalmi, a Felügyeleti és Fegyelmi, valamint a Politikarendészeti Osztállyal. Az egyes szervezeti egységek külön részlegekre oszlottak:

- az Elnöki Osztály a titkári hivatalból, a fegyelmi, az engedélyügyi, a gazdasági és a gépkocsi alosztályból állt;

- a Közigazgatási Osztály részeit az útlevél és az erkölcsrendészet alkotta;

- a Bünügyi Osztály részlegeit büncselekmény típusok szerint szervezték;

- a Detektívtestület a detektívmunka területeinek megfelelően 7 fö- és 69 alcsoportból állt;

- a Rendőri Örség rendőr-főparancsnokság alá tartozott, amely osztályparancsnokságokból állt.

Kezdetben a budapesti rendőrségnél 22 osztály-parancsnokság müködött: I-X. kerületi, kispesti, újpesti, pesterzsébeti, csepeli, dunai I. és II., vasúti, fơkapitánysági tartalék, tanosztály, lovasosztály és kerékpáros osztály-parancsnokság. A II. világháború időszakára ez kiegészült még 4 kerületi osztályparancsnoksággal, a toloncházi, valamint az első és második karhatalmi zászlóalj-parancsnokságokkal. A kerületi osztály-parancsnokságok alárendeltségében az őrszobák állottak, az örszobák részegységei pedig az örszemkeretek voltak. ${ }^{6}$ (II.sz. melléklet)

A Magyar Királyi Állami Rendőrség, illetve 1932-től a Magyar Királyi Rendőrség szervezetéhez kapcsolódóan több kisebb-nagyobb változtatásra került sor. 1922-ben felállították a légiforgalmi rendészetet, 1924-ben pedig megszüntették a Központi Nyomozó Hivatalt. A vidéki kerületi főkapitányságok megszüntetése nyomán 1932. I. 1-től a politikai rendészeti teendőket egy szervezeti egység a Politikairendészeti Osztály látta el, amely a budapesti fökapitányság közvetlen alárendeltségébe tartozott. ${ }^{7}$ Az 1925. VI. 1-vel felállított Külföldieket Ellenőrző Hivatal feladatait 1931. II. 1-től a Külföldieket Ellenőrző Országos Központi Hivatal (KEOKH) vette át. ${ }^{8}$

1921. VIII. 1-én állították fel a budapesti rendőrségen a kerékpáros zászlóaljat, majd ennek keretében hozták létre az első motorkerékpáros osztagot. A kerékpáros részlegből fejlődött ki a színhelybiztosító őrség és a közlekedési osztály, majd 1935. VIII. 1-től a baleseti járörrendszer. ${ }^{9}$

1922. III. 12-én fökapitányi rendelet szüntette meg a fövárosban a rendőri sajtóirodát. Ezt követően a rendőri hírszolgálatot a Magyar Országos Tudósító Iroda látta el. Ez a rendelet nem aratott sikert a Napilapok Rendőri Rovatvezetőinek Szindikátusa körében. Több módosító rendelkezés után az Országos Sajtókamara felállítása kapcsán hozták létre a Rendőri Rovatvezetők Szakcsoportját. Ennek tagjaival — az elnöki osztály kebelében müködő — sajtóiroda tartott intézményes kapcsolatot. A rendőri rovatvezetők külön jelvényt és igazolványt is kaptak. ${ }^{\mathbf{1 0}}$

1932-ben megszüntették a rendőrkórházat és csökkentették a rendőrorvosok létszámát is. Kinevezett rendőrorvosok csak a budapesti fökapitányságon dolgoztak, vidéken a hatósági orvosok látták el az orvosrendőri szolgálatot. A szükebb értelemben vett rendőrorvosi teendőkre pedig szerződtettek orvosokat, akik egyben a személyzet ambuláns kezelését is ellátták. A rendőrök kórházi kezelését a honvéd kórházak vették át. ${ }^{11}$

Az első állandó szervezésü, karhatalmi rendeltetésü rendőri alegységet a budapesti rendőrség kebelében hozták létre karhatalmi századként 1932. I. 8-án, melyet 1934. IV. 16-ai hatállyal zászlóaljjá szervezetek át. 1942-ben újabb karhatalmi zászlóaljat szervezetek. ${ }^{\mathbf{2}}$

A folyamrendészeti (vízirendészeti) teendőket 1921. II. 12-től a Magyar Királyi Folyamőrség látta el. Ezeket a feladatokat 1939. VII. 1-től áthelyezték a Magyar Királyi Rendőrséghez és a Magyar Királyi Csendőrséghez. A Magyar Királyi Rendőrséghez kerültek a Magyar Királyi Folyamőrség révkapitányságai és révőrségei. A továbbiakban a folyamőrség csak honvédelmi feladatokat látott el. A budapesti rendőrségnél megszünt a Dunai Rendőrkapitányság, megmaradt azonban a Dunai 
Mentőőrség, amely a Budapesti Révkapitányság alárendeltségébe került. Ide tartozott a Csepeli Révkirendeltség is és számukra külön elöljáró szervezetet hoztak létre a Budapesti Révosztályparancsnokságot. ${ }^{13}$

1930 februárjában adták át a bünügyi rádióállomást Belügyminisztériumi Közbiztonsági Rádiótelep néven. Az új lehetőséget nem csupán a rendőrség használta. ${ }^{14}$

A Magyar Királyi Rendörség struktúrája dinamikusan fejlödött. A kor követelményeinek megfelelő szervezet volt, amely továbbfejlesztette a fővárosi rendőrség az első államosított rendőrség hagyományait és tapasztalatait. A tradícióőrzést és a modernizációt egyaránt magába foglaló folyamatot érzékelhetünk a személyi állomány jellemzőinek a vizsgálata során is.

Az országos rendörség testületi tagjainak állománycsoport szerinti megoszlása jelentős mértékben megegyezett a Budapest székesfővárosi rendőrség korábbi gyakorlatával.

\section{A humán viszonyok}

1. Egyenruhát és fegyvert viselő személyzet csoportjai voltak: a / fogalmazói kar, b / felügyelöi kar (tisztviselők = tisztek), c / örségi személyzet.

2. Polgári ruhás és fegyver viselésére nem jogosított személyzet csoportjai voltak: a / a rendőrség müködését kiegészítő detektív személyzet, $\mathrm{b}$ / a rendőrség müködését támogató felsőfokú képzettségü személyzet (orvosok stb.), valamint középiskolai végzettségü számvevőségi és pénzügyi szakszemélyzet, c / az irodában müködő kezelési szakbeli alkalmazottak, d / kézbesítők és szolgák.

Az 1. a / és b / , valamint 2. b / és c / pontba tartozók alkották a tisztviselöi kart.

A fegyver viselésére nem jogosított személyzet tagjai nem viselhettek kardot és hadifegyvernek minősülő pisztolyt. A detektíveknek azonban kötelező volt olyan rövid csövü revolver viselése, amely nem minősült hadifegyvernek. A detektívek azonos szinten álltak a kezelöi tisztviselöivel, de külön csoportot alkottak.

A fogalmazói karon belül a rendőrtisztviselőket nyolc rangosztályba sorolták: a rendőrfőkapitányok a IV., a főkapitány-helyettesek az V., a rendőr-fötanácsosok a VI., a rendőr-tanácsosok a VII., a rendőr-kapitányok a VIII., a rendőr-fogalmazók a IX. és X., a rendőr-segédfogalmazók a XI. fizetési osztályba tartoztak, a rendőr-fogalmazó gyakornokok nem tartoztak fizetési osztályba csak a kinevezésük után.

A felügyelöi karban lévők négyféle rendfokozatba tartoztak: rendőr-főparancsnok (csak Budapesten V. másutt VI. fizetési osztály), rendőr-főfelügyelő VII. és VIII., rendőr felügyelő IX. és X., rendőr-segédfelügyelö XI. fizetési osztály, a felügyelő gyakornokok pedig a fogalmazó gyakornokokhoz hasonlóan.

Az örségi személyzet két rangosztályból állt. Ezen belül a legénység számára öt rangot alakítottak ki: próbarendőr, rendőr, rendőr őrmester, rendőr törzsőrmester, rendőr főtörzsőrmester. $\mathrm{Az}$ örszemélyzet felső rétegét képező altisztek számára kétféle rangot rendszeresítettek: a rendör alhadnagyot és a rendőr tiszthelyettest (mindkettőn belül három-három fizetési osztállyal).

A detektívek négy rangosztályba tartoztak: detektív főfelügyelő VII., detektív felügyelő VIII. IX., detektívek X. XI. fizetési osztály, végül pedig detektív gyakornokok.

$\mathrm{Az}$ orvosi karban öt rangrendszer létezett: rendőrfőorvos V., rendőrorvos-főtanácsos VI., rendőrorvos-tanácsos VII., kerületi rendőrorvos VIII., és rendőrorvos IX. és X. fizetési osztály.

Számvevőségi rangok voltak: számvevőségi fötanácsos VI. és VII., számvevőségi tanácsos VIII. és IX., számellenőr X. és számtiszt XI. fizetési osztály.

A pénztári szakban öt rendfokozat volt: föpénztárnok VII., főellenőr VIII., pénztári fötiszt IX., pénztári tiszt X. és pénztári segédtiszt XI. fizetési osztály.

A kezelési szakon összesen öt rang létezett: segédhivatali föigazgató VII., segédhivatali igazgató VIII., hivatali fötiszt IX., hivatali tiszt X. és hivatali segédtiszt XI. fizetési osztály.

A hierarchia legalján az altisztek és a szolgák álltak: müszaki altisztek, szakaltisztek, I. osztályú altisztek, II. osztályú altisztek és kisegítő szolgák. (III.sz. melléklet)

$\mathrm{Az}$ államosított rendőrség a budapesti rendőrség fizetési táblázatát vette át, amelyet pedig 1881ben - az állami fizetési rendszer figyelembe vételével — hoztak létre. A rendöri fizetési rendszer 65 éves müködése során természetesen több változtatásra is sor került, amelyek elsősorban a szakok, illetve azokon belüli rangok fizetési osztályokba sorolásának a módosításából állt. Magán a rendszeren lényegi változtatást nem eszközöltek. Erre még 1944-ben sem került sor, amikor a Magyar Királyi Rendőrségnél áttértek a katonai rangok használatára, hiszen a katonai rangokhoz kapcsolódó fizetéseket is az állami fizetési táblázatba sorolták be. Az örszemélyzet esetében ugyan az e szakba tartozó személyi állomány nem kerülhetett besorolásra az állami fizetési rendszerbe, azonban a 
legmagasabb őrszemélyzeti ranggal rendelkezők pályájuk csúcsán — tekintélyes szakmai gyakorlati idő elérése nyomán - fizetésük hasonló nagyságrendủ volt, mint a fogalmazói vagy felügyelői szak legalsóbb fizetési osztályaiban tevékenykedő fiatal fogalmazók és felügyelők fizetése.

A gyakornoki rendszer bevezetésének az volt a lényege, hogy a gyakorlati munkavégzés során váljék nyilvánvalóvá, hogy a különböző szakokra bejutni kívánó személyek egyénisége milyen mértékben harmonizál a szakokban teljesítésre kerülő munka elvárásaival.

A külön altiszti rangok helyett kezdetben a I. II. és III. osztályú felügyelö-helyettesi elnevezést használták. Az 1920-as években a gépkocsi üzemeltetéssel kapcsolatos munkaköröket betöltők - a szakaltisztek csoportjának gépkocsizó testületébe tartozó tagjai — külön rangokat kaptak. Az 1930-as években azonban a gépkocsivezetői rangokat megszüntették. ${ }^{15}$

A közigazgatási hierarchia fizetési osztályaiba csupán a tisztviselői kar különböző szakjai (fogalmazói, felügyelői, orvosi, számvevőségi, pénztári és kezelői) tartoztak. Ez alól csupán a detektívek alkottak kivételt, akiket szintén a fizetési osztályokba soroltak. A rendőrség testületi tagjai tehát valamennyien rendelkeztek valamilyen ranggal. Ezek azonban 1944-ig nem katonai, hanem speciális rendőri rendfokozatok voltak. Az egyenruha viselésére nem jogosult személyi állomány értelemszerüen nem .viselhette, de természetesen használhatta a rangját. Az egyenruhát viselők rangjának megjelenési -formája is eltért a katonai rangokétól. A rendőri rangokat nem hatágú csillaggal jelölték, mint a honvédségnél, illetve a csendőrségnél, hanem - a katonai tisztviselőkéhez hasonlóan - úgynevezett rózsácskával. A fegyveres szolgálatot ellátók esetében a rendfokozatot csillagrózsácska jelölte, a fegyvertelen szolgálatot ellátók esetében pedig rózsácska, más néven rozetta jelölte a rangot. Az arany és az ezüst színek, valamint a paszomány alkalmazásának az elve lényegében megfelelt a katonai rangoknál kialakult nemzetközi gyakorlatnak. ${ }^{16}$ A rendőrtestület tagjai attól függően rendelkeztek különböző jogosultságokkal, hogy a személyi állomány mely csoportjába tartoztak, milyen rangot viseltek, illetve milyen beosztást töltöttek be. A rendöri testületnek a szükebb értelemben vett rendőri munkát végzők karjaiba nem volt könnyű bekerülni.

A fogalmazói kar alkotta az úgynevezett „intéző rendőrség”-et. A fogalmazóknak intézkedési és bizonyos ítélkezési joguk is volt (a szabálysértési eljárásban). Ez a kar alkotta a rendörtestület elit magját. Az őrszemélyzeti parancsnoki beosztások kivételével — amit a rendőrfelügyelők töltöttek be — minden kulcspozíciót a fogalmazók láttak el. Belölük kerültek ki a gazdasági és segédhivatalok kivételével az osztályok, a kapitányságok és a fökapitányságok vezetői és szakemberei. Egyedül a fogalmazói kar tagjait lehetett feljogosítani rendőri büntetőbíráskodásra. E jogosultság azonban a beosztáshoz kapcsolódott, így azzal nem minden fogalmazó karbeli rendőrtisztviselő élhetett. A rendőri büntetőbíráskodásra a belügyminiszter minden esetben külön és névre szólóan hatalmazta fel a megfelelő beosztást betöltő rendőrfogalmazót. A fogalmazó karbeli rendőrtisztviselők végezték a vizsgálati munkát, valamint az igazgatásrendészeti teendöket is. E tevékenységükben azonban a rendőrfogalmazókat a szükséges létszámú segédszemélyzet támogatta pld. detektívek, írnokok stb.

„Végrehajtó rendörség”-nek a testület azon részét nevezték, amely a jogszabályok betartása fölött őrködött és végrehajtotta az ,intéző rendőrség” utasításait. Ide tartozott a detektív testület, a rendőri őrszemélyzet és a felügyelöi kar.

A tisztviselöi karok tagjai feljebbvalói voltak azoknak a testületi tagoknak, akik nem tartoztak a tisztviselöi karba. Ugyancsak feljebbvalói voltak az egyes karokon belül a magasabb rangúak az alacsonyabb rendfokozatúaknak. Minden testületi tag az elöljárója volt továbbá annak a kollégájának, akit szolgálattételre hozzá osztottak be.

A rendőrséget polgári őrtestületnek, nem pedig katonailag szervezett őrtestületnek tekintették, hangsúlyozták azonban a fegyelmet, különösen az örszemélyzet esetében. Az alaki formaságok betartása az egyenruhás állomány kötelessége volt, de példás munkarend uralkodott az egyenruha viselésére nem jogosult személyi állomány körében is. ${ }^{17}$

A fogalmazói és a felügyelői karba való bejutás előfeltétele a 21 évnél idősebb, de 30 évnél fiatalabb életkor volt, a nőtlenség, az egészséges fizikai állapot, a rendezett anyagi viszonyok, a fogalmazói karhoz a jogakadémiai végzettség, a felügyelői karhoz pedig az érettségi képesítési követelmény továbbá a magyar állampolgárság. A pályázókat karrierjük kezdetén rendőr-fogalmazó gyakornokká, illetve rendőr-felügyelő gyakornokká nevezték ki. A kinevezetteket egy éves próbaszolgálatra osztották be, ahol a rendőri hivatás minden ágával megismerkedhettek. Az egy év leteltével a gyakornokok vizsgát tettek. A felügyelő gyakornokok esetében ez csupán a szerzett ismeretekre vonatkozott, a fogalmazó gyakornokok pedig ekkor tehették le a gyakorlati közigazgatási vizsga elméleti részét. Ezt követően a fogalmazó gyakornokokat segédfogalmazóvá nevezték ki, nekik két éven belül kellett letenniük a gyakorlati közigazgatási vizsga belügyi szakvizsgáját. A felügyelő gyakornokokat 
pedig tiszti tanfolyamra bocsátották, amelynek időtartama egy év volt, melyet egy éves szolgálati gyakorlat követett ezen időszakban azonban önállóan még nem tevékenykedhettek. A tiszti tanfolyam eredményes elvégzése nyomán, illetve a gyakorlati közigazgatási vizsga belügyi szakvizsgájának eredményes letétele után a rendőr segédfogalmazókat rendőr fogalmazóvá, a tanfolyam hallgatóit pedig rendör felügyelővé léptették elö.

A felügyelői és a fogalmazói kar számára a VIII. fizetési osztályba jutáshoz második vizsga is szükséges volt, amelyhez posztgraduális képzés keretében juthattak el.

A rendőrtisztviselők továbbképző tanfolyamára — amelynek időtartama hat hónap volt — azok a legalább a X. fizetési osztályba tartozó fogalmazók és felügyelők jelentkezhettek, akik a felügyelöi szakon legalább 12 évet, a fogalmazói szakon pedig minimum 8 évet töltöttek el. ${ }^{18}$

A fogalmazói és a felügyelöi követelményeknél alacsonyabb színvonalon ugyan, mégis magas szinten határozták meg a rendőri őrséghez való bejutás feltételeit is. Rendőrnek az jelentkezhetett, aki 21 évnél idősebb de 26 évnél fiatalabb, nőtlen, erős, egészséges testi felépítésü, minimum 170 centiméter magas, katonai szolgálatot letöltött, magyarul írni, olvasni és beszélni tudó (elemi iskolai végzettségü), feddhetetlen előéletü magyar állampolgár volt. A lovas rendőrségnél a lovagolni tudás is az előfeltételek közé tartozott.

A pályázókról rejtett környezettanulmányt készítettek. Azokat bocsátották a felvételi bizottság elé, akiknek az erkölcsi állapotát és magatartását rendben találták.

A rendőrök számára három éves próbaidőt határoztak meg. A próbaidő első évében el kellett végezniük a rendőrújonc iskolát. Az eredményes rendőrképesítő vizsga után kezdődhetett a két éves próbaszolgálat. A jelöltet akkor lehetett a rendőrségnél véglegesíteni, amikor a próbaszolgálat kifogástalan letöltését követően az újabb orvosi vizsgán is megfelelt. ${ }^{19}$

A rendőr legénységi karból az altiszti karba az altisztképző tanfolyam sikeres elvégzése után lehetett bekerülni. A tanfolyamra az juthatott be, aki két évet eltöltött a fötörzsőrmesteri rendfokozatban és akit szolgálati elöljárója az előléptetésre és az altiszti kiképzésre alkalmasnak minősített. Az altiszti tanfolyamot sikeresen elvégzőket lehetett rendőr-tiszthelyettessé előléptetni. ${ }^{20}$

Ugyancsak magas követelményeket támasztottak azokkal szemben, akik a detektívtestületbe szándékoztak belépni. Detektívnek az jelentkezhetett, aki 24 évnél idősebb, de 40 évnél fiatalabb férfi, feddhetetlen elöéletü, egészséges, a rendőrorvosi vélemény szerint detektív szolgálatra alkalmas, legalább négy gimnáziumot, vagy annak megfelelő iskolát végzett magyar állampolgár volt. A jelölteket detektív gyakornoknak vették fel. A próbaidő másfél év volt. Ez alatt kellett elvégezni a detektív tanfolyamot és letenni a detektív vizsgát, illetve kifogástalan szolgálatot teljesíteni. Ezt követően léptették elő a detektív gyakornokot detektívvé.

Detektív felügyelővé azok voltak előléptethetők, akik elvégezték a detektív felügyelöi tanfolyamot, amelyre 15 évi szolgálati idővel rendelkező és legalább a IX. fizetési osztályban dolgozó detektívek jelentkezhettek. Érettségizettek vagy azzal megegyező katonai iskolát végzettek számára a szükséges szolgálati idő 12 évre, a föiskolai képesítésủek számára pedig 8 évre volt csökkenthető. ${ }^{21}$

A Magyar Királyi Rendőrségnél azok, akik nem háttértevékenységet folytattak, hanem a rendőri munka valamely részét végezték, csak az elméleti felkészítésnek és a próbaidö letöltésének valamilyen kombinációjával kerülhettek beosztásba, az adott kar felső beosztásaiba pedig újabb, posztgraduális jellegü tanfolyam és vizsga váltak kinevezhetővé. Egyébként a karon belüli rendfokozati előléptetés feltétele a kivárási idő letöltése volt. Egyes tisztviselői karokban, illetve a legénységnél, valamint a detektív testületeknél is néhány ranghoz több fizetési osztály tartozott. A magasabb fizetési osztályokba a nagyobb gyakorlattal rendelkezőket helyezték.

Szigorú követelményrendszer érvényesült — korabeli szóhasználattal élve — ,a rendörség müködését támogató" orvosok, számvevőségi, pénztári, valamint kezelési szakszemélyzet, továbbá a hivatali altisztek és szolgák estében is. Az orvosokat csak törvényszéki vizsgával, valamint bőr- és nemibeteg szakorvosi képesítéssel lehetett rendőrorvossá kinevezni. A pénztári és számvevőségi tisztviselőknek középiskolai végzettséggel, illetve államszámviteli államvizsgával kellett rendelkezniük. A kezelési szakhoz elégséges volt a négy polgári, csak az igazgatói és a föigazgatói rangokhoz kellett az érettségi. A kezelési szakra jelentkezőknek emellett a belügyi kezelési vizsgát is le kellett tenniük, így voltak véglegesen kinevezhetők. A hivatali altiszti fokozatok konkrét beosztásokhoz kapcsolódtak. Szakaltiszteknek minősültek például a raktárosok, a segédgépészek stb. A szakaltiszteket két évi, a hivataltiszteket pedig öt évi kifogástalan munka után véglegesítették. ${ }^{22}$

A budapesti rendőr-főkapitányt a kerületi rendőr-főkapitányságok vezetőit, majd a vidéki rendőrfőkkapitányt és a rendőrség tisztviselői karának VI. fizetési osztálynál magasabb fizetési osztályba tartozó tagjait beleértve a detektíveket is az államfő nevezte ki a belügyminiszter javaslatára. 
A tisztviselöi karok többi tagját a belügyminiszter nevezte ki. Az örségi személyzet tagjainak kinevezése az illetékes fökapitány kompetenciájába tartozott. A hivatali altiszteket, szolgákat, díjnokokat a kapitányságvezetők alkalmazták. A rendőrkapitányságok vezetői — mint szakértők tagjai voltak a hatósági területükön müködő törvényhatósági bizottságnak. ${ }^{23}$

A rendőrség személyi állományában a racionális arányok uralkodtak. A Magyar Királyi Államrendőrség kiépítésekor csaknem 16000 fő volt a testület létszáma. A számvevők, kezelők, díjnokok, altisztek, a szolgaszemélyzet és az orvosok együtt mintegy 800-an voltak. A detektívek létszáma is elérte az 1100 föt. A fennmaradó, mintegy 14000 ember alkotta az egyenruhás személyi állományt. Ezen belül a fogalmazói karhoz 250 -en, a felügyelöi karhoz pedig 750 -en tartoztak. A rendőrség személyi állományának döntő hányadát az örszemélyzet alkotta csaknem 13000 fővel. A rendőrség fegyveres és fegyver nélküli állomány, illetve az egyenruhás és a polgári ruhás karok közötti arány a későbbiek során sem változott lényegesen, de a rendőrség létszámát a terület-visszacsatolásokig folyamatosan csökkentették.

1928-ban már csupán 680 fő volt a fogalmazói és 214 fő a felügyelői kar létszáma, az őrszemélyzet 7880 fö́t számlált. Ebből 4300 fő Budapesten, 3580 fö pedig vidéken teljesített szolgálatot. Ekkor a Magyar Királyi Államrendőrség létszáma a detektívekkel, orvosokkal, számvevőkkel, kezelőkkel és a pénztári szakon dolgozókkal együttesen mintegy 12000 főt tett ki. Hozzávetőlegesen ezen a szinten stabilizálódott a rendőrség létszáma a Magyar Királyságban a területvisszacsatolásokig. Az elcsatolt területek egy részének visszatérése után újra gyarapították a Magyar Királyi Rendőrség létszámát. 1942-ben a fogalmazói kar már 873, a felügyelői kar pedig 345 tagot számlált, továbbá az örszemélyzet létszáma 12784 fốt tett ki, közülük 6460 fö Budapesten, 6324 fő pedig vidéken teljesített szolgálatot.

A detektíveket is figyelembe véve 14000 fönyi beosztott mellett 1218 rendőrtiszt (fogalmazó és felügyelő karbeli tisztviselö) dolgozott, vagyis átlagosan 11 fönyi őr- és detektív személyzeti tag jutott a tisztikar egy-egy tagjára.

Nem voltak a rendőrségnél felduzzadt létszámú parancsnokságok sem. A tisztek döntő többsége a kapitányságok osztályain végezte munkáját, az első- vagy a másodfokú hatósági jogkörből adódó konkrét ügyeket intézte.

Egy-egy vidéki kerületi fökapitányság létszáma a 40 fö́t sem érte el. Hasonló létszámmal müködött a vidéki főkapitányság is 1932-től. E szervezetekben néhány fogalmazó karbeli szakelőadó, három-négy rendőrfelügyelő, s a segédhivatal müködött. A fökapitányság őrzésére a helyi rendörség rendelt ki örszemélyzetet. 1931 elött azonban minden kerületi fökapitányságnál oktató és tartalékosztály is létezett. Ennek a létszámkeretét terhelték a tanfolyamok hallgatói, a kerületi tartalék, a jóléti intézményekben foglalkoztatott testületi tagok, valamint a végelbánás alá esők és a fegyelmileg felfüggesztettek. A kerületi főkapitányságok felszámolásával a tartalékosztályok is megszüntek, csupán a vidéki főkapitányság rendelkezett egy tartalékosztállyal. A körzeti szemlélő központok már átlagosan csupán 10 fő körüli létszámmal látták el felügyeleti tevékenységüket. ${ }^{24}$

A magas színvonalú szakmai felkészültség hiányában valószínűleg nem tudott volna a Magyar Királyságban a viszonylag kis létszámú rendőrség hatékonyan müködni. A csekély létszám a testület tagjai részéről komoly munkát feltételezett. A személyi állománnyal szemben támasztott magas kvalifikációs igényt és a rendőri szolgálat nehézségeit a személyi állomány jó anyagi ellátásával, megbecsülésével, a szolgálati feltételek lehető legkedvezőbb szinten tartásával voltak kompenzálhatók. A két világháború közötti Magyar Királyságban ezt sikerült létrehozni, fenntartani és fokozatosan javítani.

Az örszemélyzeti legénység zsoldja 1928-ban havi 50 és 140 pengő között mozgott, 1942-ben pedig ez az összeg már 109-től 283 pengőig terjedhetett. Az illetmények azonban nem csak a zsoldból álltak. Ide tartozott még a rendőri pótdíj, az élelmezési általány, valamint a lakbérhozzájárulás, ami a lakbér teljes összegét jelentette. A lakbér — amely már nem csak a rangtól, hanem a család nagyságától is függött - 25-től 220 pengőig terjedhetett a XX. század negyvenes éveinek az elején. A rendörök családi pótlékra is jogosultak voltak. (IV.sz. melléklet)

Az őrszemélyzet illetménye adómentes volt, csupán másfél százalékos nyugdíjjárulék terhelte. A személyi állomány valamennyi járandóságát havonta kapta meg, és ha elseje munkaszüneti napra esett, akkor a megelőző napon fizettek.

A Magyar Királyi Rendőrség személyi állományának nyugdíja — megfelelő szolgálati idő után a zsold teljes összegét is elérhette. A nyugdíj összegébe a rendőri pótdíjat is beszámították. A lakbérhozzájárulást a nyugdíjasok is megkapták. 
Az özvegyek özvegyi nyugdíjként a férj fizetésének 50 \%-át kapták meg. Akinek azonban a férje szolgálatteljesítés közben vesztette életét, özvegyi nyugdíj címén a teljes nyugdíj fizetésében részesült. A kiskorú gyermekek után az özvegyek számára is járt a családi pótlék, amelyet nevelési járuléknak neveztek és az özvegyi nyugdíj 1/5-ét tette ki. (V.sz. melléklet)

Az őrszemélyzet gyógyköltségeit az állam fedezte. A szolgálati álattal foglalkozók ló-, illetve ebápolási pótlékban részesültek.

A személyi állomány kedvezményes árú vasúti jegy vásárlására szolgáló arcképes igazolványra volt jogosult. Kiküldetés esetén a rendőr útiköltségét és szállásdíját megtérítették és napidíjat is kapott. $^{25}$

A Magyar Királyi Rendőrség személyi állománya számára ez a javadalmazás szilárd egzisztenciát biztosított és jobb körülmények közé juttatta a testületi tagokat, mint a „civil életben” hasonló képesítéssel munkát vállalókat. A pozitívumok a fizetés mértékében és a különböző kedvezményekben, valamint a szilárd egzisztenciában jelentkeztek. A rendőrségtől némileg eltérő képet mutatnak a két világháború közötti Magyar Királyság határőrizeti szervezetei.

\section{A két világháború közötti magyar határörizet}

A Magyar Királyság határőrizetében számos hatóság vett részt ugyan, de 1921-től meghatározó szerep jutott a Magyar Királyi Vámörségnek és utódszervezeteinek. A két háború közötti magyar határőrizeti változások a magyar határőrizet történetében a határőrizeti szervezetek egyik legdinamikusabb struktúraváltozási folyamatát képezték.

A Magyar Királyi Vámőrség hivatalosan a Magyar Királyi Pénzügyminisztérium szervezeteként müködött. A minisztériumban a XX. majd a XIX. Főosztály felügyelte a testületet. A XIX. Főosztály azonban csak névleg tartozott a Magyar Királyi Pénzügyminisztérium alá, a valóságban a Magyar Királyi Honvédelmi Minisztérium kikülönített részeként funkcionált. A nem határvédelmi teendők irányításával az 1930-as évektől honvédelmi tárca XIX. Főosztálya foglalkozott a földi főcsoportfőnök első csoportfönökének alárendeltségében. ${ }^{26}$

A trianoni békediktátum nem csupán megcsonkította az országot - elcsatolva területének mintegy 2/3-át, lakosságának pedig több mint felét — hanem egyben kiszolgáltatott helyzetbe is hozta azáltal, hogy a magyar haderő létszámát 35000 főben maximálta és a fegyverzetét is erőteljesen korlátozta. Mindegyik kisantant ország hadereje egyedül is az engedélyezett magyar haderőnél lényegesen erőteljesebb volt. Emellett Magyarországtól elvonta a sorozás lehetőségét is. Ez utóbbi feltétel azonban kivitelezhetetlen volt, mivel - még a nyomott létszámú haderő személyi állományának a feltöltéséhez szükséges - kellő számú önként jelentkező sem állt rendelkezésre. Ezrét az ANTANT kénytelen volt elfogadni a kényszertoborzást, amely lényegében a sorozás átkeresztelt formája volt. ${ }^{27}$

A trianoni békediktátum elcsatolásai nyomán megmaradt Magyarország ipari centrumaihoz az országhatárok oly közel kerültek, hogy azok néhány órás sikeres ellenséges előrenyomulással elérhetőkké váltak. A kis létszámú magyar hadseregnek pedig esélye sem volt arra, hogy az országot egy esetleges ellenséges támadással szemben megvédje. Ezért az ország vezetése rejtett haderőnövelésre törekedett. Az egyik módszer az alakulatok ikrezése volt. Ez abból állt, hogy a legális katonai alakulatok mellé szerveztek egy illegálisat is. Az iker alakulatok pedig soha nem lehettek egy helyen. Ily módon — 1927-ig az ország területén müködő — Szövetségközi Ellenőrző Bizottság tagjai nem tudták a turpisságot leleplezni.

A haderőrejtés másik bevett eszköze volt, amikor rendvédelmi szervezet kötelékében bújtattak el katonai alakulatokat. A Magyar Királyi Vámőrség esetében ez azt jelentette, hogy a Magyar Királyi Honvédség gyalogezredeinek 1/3-át a vámőrség szervezetében rejtették el. A magyar haderö vámőrségbeli rejtése azért is vált fontossá, mert így a csapatok egy részét a határ mellé lehetett telepíteni. Ennek pedig azért volt jelentősége, mert ezáltal lassítani lehetett az ellenséges előrenyomulás ütemét. Az így nyert idő alatt pedig részben behívható volt a mélységi területek férfilakossága még azt megelőzően, hogy az ország területét lerohanták volna. Egyben pedig megelőzhetővé vált az a nemkívánatos helyzet, hogy a fegyveres konfliktus tárgyalásos úton történő rendezésének időszakára a támadó kész tényekkel a háta mögött ülhessen tárgyalóasztalhoz. ${ }^{28}$

A Magyar Királyi Vámőrségnek tehát nyílt (határőrizeti) és rejtett (határvédelmi) feladata is volt, amelyet nyílt szervezettel és rejtett szervezettel valósított meg. Ezt a fajta megoldást az tette lehetővé, hogy az ANTANT a rendvédelmi testületek gyarapításától nem zárkózott el. Ily módon álhatott elő az a helyzet, hogy a magyar rendőrség és csendőrség a csonka Magyarországon a történelmi Magyarországon müködő létszámmal azonos létszámú szervezetként tevékenykedhetett, amely mellé 
még a Magyar Királyi Vámőrség ${ }^{29}$ és a Magyar Királyi Folyamőrség felállitását is engedélyezte az ANTANT. ${ }^{30}$

1931-ben a Magyar Királyi Vámőrség 7 kerületből, 54 szakaszból és 151 őrsből állt. (VI.sz. melléklet)

A kishatárforgalmi határátkelőhelyeket a két világháború közötti Magyar Királyságban a Magyar Királyi Vámőrség és utódszervezete felügyelte. ${ }^{31}$

Kezdetben a Magyar Királyi Vámőrség szervezetéhez vezényelve koncentrálták a társhatárőrizeti szervezetek határőrizeti feladatok ellátásában részt vevő erőit: 2177 csendőrt, 3754 honvédet, 261 rendőrt és 800 pénzügyőrt azaz összesen 6992 főt. E létszámot fokozatosan kívánták felváltani a Magyar Királyi Vámőrség 4913 före tervezett személyi állományával. Ebből a létszámból azonban kezdetben csupán 4210 föt engedélyeztek, bár az ANTANT részéről már 1922-ben felmerült, hogy valójában 6262 fö szükséges. Végül is 4500 fônyi létszámot engedélyeztek a Magyar Királyi Vámőrség számára.

A tiszti állomány az országos felügyelőségen, a kerületeknél és a szakaszoknál teljesített szolgálatot. Egy-egy szakaszhoz általában négy-hat tisztet neveztek ki.

Az őrsök létszáma 5 és 14 fö között mozgott, a vámör szakasz-parancsnokságok pedig 16 fővel müködtek. A szakaszok alá úgynevezett utazást ellenőrző őrsök is tartoztak, amelyek egy-egy altiszt vagy tisztes vezetésével a kishatárforgalmi határátkelőhelyeken és a kevésbé forgalmas távolsági határátkelőhelyeken ellenőrizték a határforgalmat. ${ }^{32}$

A Magyar Királyi Vámőrséget 1932 őszén szervezték át Magyar Királyi Határőrséggé. A volt vámőr kerületek a székhelyükön maradtak és mint határőr kerület-parancsnokságok magasabb parancsnokság jelleggel müködtek. A határőr kerület-parancsnokságok müködési területén és névleges alárendeltségében egy-egy határör ezredet hoztak létre. Az ezredek szervezete, fegyverzete stb. minden tekintetben megegyezett a Magyar Királyi Honvédség gyalogezredeivel. A határörizethez azon kívül, hogy látszólag a kerület-parancsnokságok alá rendeleték azokat — nem sok közük volt, a valóságban a vegyesdandárok, harmadik, rejtett ezredét képezték. (VII.sz. melléklet)

A Magyar Királyi Határörség kerületeinek másik, különálló részét az úgynevezett határszolgálatosok alkották. A korabeli terminológia ezzel a névvel különböztette meg a határörizeti feladatokat ellátókat a határvédelemre létrehozott szervezettől. A határőr kerület-parancsnokságok alárendeltségébe három osztály tartozott, az osztályok pedig három szárnyból álltak, végül a szárnyak általában 4-6 határőr örs munkáját irányították. Az osztály- és szárny-parancsnoki helyek tiszti beosztások voltak. A 7 határör kerület-parancsnokság alárendeltségébe 24 osztály, 63 szárny és 155 örs tartozott. Az örsök személyi állományának a létszáma általában 10 és 19 fö között mozgott, leggyakrabban 14 és 19 fö volt. ${ }^{33}$

Kisebb módosításokkal ez a struktúra müködött 1938-ig, amikor a Magyar Királyi Határőrséget Magyar Királyi Honvéd Határvadászokká szervezték át. A határvadászok szervezete eltért a Magyar Királyi Határőrségétől. 1938 végén 24 határvadász zászlóaljat hoztak létre. A határvadász zászlóaljak két típusát különböztették meg, az alacsony és a magas állományúakat.

A magas állományú határvadász zászlóaljakat nehézfegyverzettel is ellátták. A zászlóaljparancsnokság alárendeltségében a zászlóalj közvetlenek mellett — hét század állt, ezekből csak egy volt portyázó század, amely a határőrizeti teendők ellátására volt hivatott. A portyázó századokhoz 5-8 határvadász őrs tartozott, a személyi fegyvereken (pisztoly, karabély) kívül objektumvédelmi fegyverként örsönként egy-egy golyószóróval is rendelkeztek.

$\mathrm{Az}$ alacsony állományú határvadász zászlóaljak szervezete három századból és a zászlóalj közvetlen szakaszból állt. A hozzájuk tartozó portyázó század viszont semmiben sem tért el a magas állományú határvadász zászlóaljak portyázó századaitól.

A határőrzés feladatait a magas és az alacsony állományú zászlóaljaknál is a portyázó századok végezték, amelyek álosztály jelleggel müködtek. A zászlóalj többi alegysége a határvédelem részét képezte. A Magyar Királyi Határőrségnek Magyar Királyi Honvéd Határvadászokká történő átszervezésével megszünt a testület pénzügyminisztériumi alárendeltsége. A határvadász zászlóaljak személyi állománya 14717 fớt tett ki, melyből 3222 -en tartoztak a határszolgálatosokhoz, a 24 portyázó századhoz beosztva. A portyázó századok parancsnokságain csak 8-8 fő teljesített szolgálatot, a személyi állomány döntő többségét az őrsökre helyezték, amelyek létszáma 6 és 17 fö között mozgott. A portyázó századok alárendeltségében kezdetben 178 őrs müködött.

1939 elején csoportosították a határvadász zászlóaljakat az állomáshelyük meghagyásával. A zászlóalj csoportok élére 8 határvadász dandár-parancsnokságot szervezetek, ezek töltötték be a volt 
Magyar Királyi Határőrség került-parancsnokságainak a funkcióit. A területvisszacsatolások során 1939-ben a zászlóaljak számát 29-re növelték. ${ }^{34}$ (VIII.sz. melléklet)

1941-ig újabb szervezeti elemeket is beiktattak a magyar határôrizet szervezetébe a Magyar Királyi Honvéd Határvadász testület portyázó osztályait és az erődszázadokat. Gyergyószentmiklóson létrehozták a IX. Magyar Királyi Honvéd Határvadász Dandár-parancsnokságot, egyes dandárparancsnokságokat pedig megszüntettek. 1941 végén már csak nyolc dandár-parancsnokság müködött. A honvéd határvadász portyázó osztályok csak portyázó századokból és az osztály-parancsnokságokból, valamint az utóbbiak alá rendelt gazdasági hivatalból álltak. Felállítottak 11 erődszázadot is, amelyeket a Kárpátok bércei között kialakított erődvonalakba telepítettek. Feladatuk a határvédelemre korlátozódott. A területvisszacsatolások után határör ezredeket is létrehoztak. ${ }^{35} 1941$ végére azonban megszüntették a határvadász erők ezred szervezésű részeit, a helyüket pedig zászlóaljak és portyázó osztályok vették át.

A területrevízió után kilenc portyázó osztály, 16 határvadász zászlóalj, 1 határvadász dandár és ezekben a határőrzés tulajdonképpeni elvégzésére összesen 53 határportyázó század müködött. A portyázó század-parancsnokságok 342 őrsöt irányítottak. A határvadászok 27592 fönyi személyi állományából 9475 fö volt határszolgálatos.

Nem mindenki értett egyet azonban a magyar határ őrzésének ezzel a szervezetével. A strukturális kérdésekről szakmai körökben változó erővel ugyan, de állandó vita folyt. Csendőrségi berkekben már a Magyar Királyi Vámőrség létrehozását is nehezményezték. A monarchiai és a Kárpát-medencei hagyományok alapján úgy gondolták, hogy a határőrizetben a kishatárforgalom ellenőrzését a csendőrségnek, a távolsági határforgalom ellenőrzését pedig a rendőrségnek kellene végeznie, a határrend feletti felügyelet teendöit pedig meg kellene osztani a két testület között. Tervezetüket eljuttatták a kormányzóhoz, de annak környezete — a véderö álcázott növelésének a lehetőségére számítva - a Magyar Királyi Vámőrség létrehozását szorgalmazta.

A határörzést illetően a Magyar Királyi Honvédségen belül a legszélesebb körben az a felfogás terjedt el, hogy azt már békében is alá kell rendelni a határvédelemnek. A határ örzése számára csak a legszükségesebbeket biztosítsák, a felszabaduló energiákat pedig, a határvédelemben kell hasznosítani.

A vesztes háború után a határőrizeti struktúra nélkül maradt országban létrehoztak ugyan egy határőrizeti szakmai szervezetet, de eleve azzal a céllal, hogy betöltse a határvédelmi erők fedőtestületének a szerepét is. A Magyar Királyi Vámőrség szervezete azonban nem felelt meg a rejtett feladatok ellátásának, csupán a határ őrzésére volt alkalmas. ${ }^{36}$

A két világháború közötti Magyar Királyság határörizetének szervezettörténete tulajdonképpen nem más, mint a határvédelmi erők fejlesztésének a története. A szervezet fejlesztésének folyamatában a határőrizeti vezetési szervezeti egységek fokozatos kiiktatása figyelhető meg. A folyamat egyenes következményeképpen romlott a szakszerü irányítás. Ugyanakkor a határvonal hosszának növekedésével relatíve csökkentek a határszolgálatos erők.

A területrevíziók nyomán a kishatárforgalmi határátkelöhelyek száma nem változott lényegesen az elhelyezkedésük azonban módosult. A forgalom ellenőrzésében résztvevők létszáma sem változott. A határvonal hossza azonban jelentősen megnőtt 2100 kilométerről 3385 kilométerre gyarapodott a trianoni határvonalnál lényegesen nehezebb terepen. Nem nött viszont ezzel arányosan a határszolgálatos személyi állomány létszáma a ténylegesen beoszthatók száma 2100 fő helyett mintegy 5800 före változott. ${ }^{37}$

Összességében a polgári magyar állam két világháború közötti időszakára a trianoni békediktátum nyomta rá a bélyegét. Ez olyan helyzetet hozott létre a Kárpát-medencében, amely egyrészt lassította a térség fejlödését, másrészt pedig az elcsatolt területek társadalmának egyes rétegeit a győztes nagyhatalmaktól függő hatalomgyakorlásban tette érdekeltté. ${ }^{38}$

A kisantant országok haderöi egyenként is a magyar hadsereg többszörösét tették ki. Fegyverzeteik fejlesztését semmi sem korlátozta. A magyar ipari centrumokhoz pedig olyan közel kerültek a határok, hogy ezen centrumok néhány órás eredményes előrenyomulással elfoglalhatók voltak. Mivel a kisantant államok is tisztában voltak a trianoni békediktátum rabló tartalmával — bár azt hivatalosan soha nem ismerték el, sőt az ellenkezőjét hirdető propagandát folytattak - féltek attól, hogy a rablóbéke javait egyszer vissza kell szolgáltatniuk. Ennek megakadályozása érdekében hadseregeik maradék Magyarország ellenes támadási terveit is összehangolták. ${ }^{39}$

Ilyen körülmények között a magyar vezetés arra törekedett, hogy:

- minél nagyobb katonai erőt rejtsen el;

- a határ mentén - lehetőleg rejtve — katonai alakulatokat állomásoztasson, egy esetleges ellenséges támadás lassítása céljából; 
- mélységi területen pedig fenntartsa a lakosság mozgósításának a lehetőségét. ${ }^{40}$

A magyar vezetés tudatában volt annak, hogy egy esetleges kisantant támadásnak az ország ugyan nem tud ellenállni, azonban bízott abban, hogy diplomáciai síkon elérheti az estleges agresszió visszavetését. Más lehetősége nem is volt az országnak. A diplomáciai tárgyalások számára kívántak tehát kedvezőbb pozíciót teremteni azáltal, hogy megakadályozzák az ország gyors lerohanását. ${ }^{\mathbf{4 1}}$

Ennek érdekében a katonai szakembereket leszerelték ugyan a hadseregtől, azonban a felduzzasztott létszámú rendvédelmi testületeknél helyezték őket el. Úgy gondolták ugyanis, hogy ezeken a helyeken kevésbé amortizálódik a katonai szaktudás. ${ }^{42}$

A vezetési pontok, közlekedési csomópontok, raktárak stb. örzésével kapcsolatos teendőket a magyar haderő átadta a rendvédelmi testületeknek. Ily módon a rendelkezésre álló csekély katonai erőt megvédték a szétforgácsolódástól.

Annak ellenére azonban, hogy a trianoni békediktátum káros hatásai érvényesültek a rendvédelemben, mégsem mondható el, hogy a két világháború közötti Magyar Királyság rendvédelme katonai ellenörzés alatt állt volna. A magyar rendvédelem testületei ugyanis a polgári közigazgatás felügyelete alá tartoztak. Ezen belül került sor bizonyos átalakításra azáltal, hogy a városi rendörségeket a központi kormány közvetlen felügyelete alá helyezték az egységes magyar rendőrség kialakításával. ${ }^{43}$

A rendőrség államosításán túlmenően — a rendvédelmi struktúrát illetően — még egy jelentős lépés valósult meg a két világháború közötti időszakban a magyar rendvédelemben. A rendvédelmi testületek személyi állományához viszonyítva jelentős létszámú határőrizeti testületet hoztak létre a központi kormányzat közvetlen alárendeltségében.

A két világháború közötti időszakban tehát megszünt az a korábbi helyzet, mely szerint a polgári magyar állam rendvédelmi testületeinek alárendeltsége megoszlott a kormány és az önkormányzatok között. Ehelyett a rendvédelem kompetenciája a kormánynál összpontosult. A trianon utáni csonka Magyarország rendvédelmi testületei személyi állományának a teljes létszáma ugyan magasabb volt mint a dualizmuskori rendvédelmi testületek létszáma, azonban a teljes személyi állományon belül az egyenruhás és a civil állomány, azaz az őrszemélyzet (közrendvédelmi személyzet) és a detektívek (nyomozók) aránya lényegében változatlan maradt. Ez alól csupán a határőrizet volt kivétel.

A korszak végén ugyan létrejött a két legnagyobb rendvédelmi testület a Magyar Királyi Csendörség és a Magyar Királyi Rendörség fúziója a két testület közös főfelügyelőségének a felállítása által, ez azonban a két testület tevékenységét jelentősen nem befolyásolta. A harccselekmények miatt azonban az 1944. VI. 21-én ${ }^{44}$ hozott azon döntés, mely szerint a Magyar Királyi Rendörségnél is katonai rendfokozatok bevezetését rendelték el már csupán csökevényesen valósult meg. Nyitva maradt azonban az a kérdés, hogy a háború után milyen irányba fejlődött volna a magyar rendvédelem, ha az ország megőrizhette volna függetlenségét és a polgári magyar állam nem esett volna a szovjet birodalom nagyhatalmi törekvéseinek az áldozatává.

Az azonban egyértelmüen megállapítható, hogy a két világháború közötti időszakban a magyar nemzeti rendvédelmet a centralizáció jellemezte, melynek során a kormányzati kompetenciák gyarapodtak, míg az önkormányzatiak mérséklődtek.

Ebben az időszakban fel sem merült a militarizmus és demilitarizmus témája. E gondolat az utókor által visszavetítve él csupán, mely során egyes dogmáknak való megfelelés szerint kívánják némely csoportok értékelni nemzeti rendvédelmünk időszakát. A kortársak előtt nyilvánvaló volt, hogy a militaritsta, illetve antimilitarista jelleg önmagában nem jelent sem rosszat sem jót. A militarizmus hasznossága lényegében a rendvédelmi tevékenység jellegétől függ. Az azonban nyilvánvaló, hogy az önkormányzatoknak alárendelt polgári rendvédelmi testületek, azaz a klasszikus értelemben vett önkormányzati rendvédelmi modell a polgári magyar állam fejlödése során már a XIX. század utolsó negyedében megbukott és a XX. század első felében a magyar rendvédelem centrális irányítása felerősödött. 
Jegyzetek:

15 047/1919. (X. 1.) ME.r.

${ }^{2}$ BORBÉLY - KAPY. I.köt. 54-55.p.

${ }^{3} 6$ 500/1931. (XI. 30.) ME.r.

4 Rendör-fökapitányságok : I. Budapesti Rendőr-fökapitányság (Budapesten) kapitányságok kerületenként, II. Vidéki Rendőrfökapitányság (Budapesten) kapitányságok városonként.

Vidéki rendörkapitányságok: 1. Baja, 2. Balassagyarmat, 3. Bánffyhunyad, 4. Beregszász, Beszterce 5. Békéscsaba, 6.Budafok, 7. Cegléd , 8. Csíkszereda , 9. Csongrád, 10. Debrecen, 11. Dés, 12. Diósgyőrr, 13. Eger, 14. Érsekújvár, 15. Esztergom, 16. Felsőbánya, 17. Gönyü, 18. Gyergyószentmiklós, 19. Gyöngyös, 20. Győr, 21. Gyula, 22. Hajdúböszörmény, 23. Hajdúnánás, 24. Hajdúszoboszló, 25. Hatvan, 26.. Hódmezővásárhely, 27. Jászberény, 28. Jolsva, 29. Kalocsa, 30. Kaposvár, 31. Karcag, 32. Kassa, 33. Kecskemét, 34. Kézdivásárhely, 35. Kiskunfélegyháza, 36. Kiskunhalas, 37. Kisújszállás, 38. Kolozsvár, 39. Komárom, 40., Kőszeg, 41. Léva, 42. Losonc, 43. Magyarkanizsa , 44. Makó, 45. Marosvásárhely, 46. Máramarossziget, 47. Mátyásföld, 48. Mezőtúr, 49. Miskolc, 50. Mohács, 51. Mosonmagyaróvár , 52. Munkács, 53. Nagybánya , 54. Nagykanizsa , 55. Nagykároly , 56. Nagykőrös, 57. Nagyszalonta , 58. Nagyvárad, 59. Nyíregyháza, 60. Pápa, 61. Pécs, 62. Rimaszombat, 63. Rozsnyó , 64. Salgótarján , 65. Sátoraljaújhely, 66. Sepsiszentgyörgy, 67. Sopron, 68. Szabadka, 69. Szamosújvár, 70. Szatmárnémeti, 71. Szászrégen, 72. Szeged, 73. Szekszárd, 74. Szentendre, 75. Szentes, 76. Székelyudvarhely, 77. Székesfehérvár, 78. Szilágysomlyó, 79. Szolnok, 80. Szombathely, 81. Túrkeve, 82. Újvidék, 83. Ungvár, 84. Vác, 85. Veszprém, 86. Zalaegerszeg, 87. Zenta, 88. Zilah, 89. Zombor .

Rendör kirendeltségek: 1. Aknaszlatina, 2. Csáktornya, 3. Fenyvesvölgy, 4. Galánta, 5. Gyékényes, 6. Hegyeshalom, 7. Huszt, 8. Jenőfalva (Magyarboly) , 9. Komját, 10. Körösmezö, 11. Kúntapolcza,12. Legenye-Alsómihályi, 13. Lökösháza, 14. Oroszvár, 15. Ökörmezö, 16. Pécsbányatelep, 17. Szencz, 18. Szentgotthard, 19.Szolyva, 20. Uszor, 21. Voloc,

BORBÉLY - KAPY. II.köt. 406-461.

${ }^{5}$ Loc.cit. 51.p.

${ }^{6}$ Loc.cit. 48-74.p.

${ }^{7}$ Loc.cit. 56.p. + 159-160.p.

${ }^{8}$ Loc.cit. 177.p.

${ }^{9}$ Loc.cit. 135-140.p.

${ }^{10}$ Loc.cit. 55.p. + 224-230.p.

${ }^{11}$ Loc.cit. 208-209.p.

${ }^{12}$ Loc.cit. 107-108.p.+ 111-114.p.

${ }^{13}$ Loc.cit. 148-150.p. ; BENCZÚR - CSONKARÉTY. 145-154.p. + 199.p. ; 1053/1920. (II. 12.) ME.r.

${ }^{14}$ REKTROR : 204.p. ; BORBÉLY - KAPY. op.cit. 61.p.

${ }^{15}$ ZEIDLER

${ }^{16}$ Loc.cit.

${ }^{17}$ VÉCSEY

18 PARÁDI: Az egységes állami fizetési rendszer és a szakterületi rendfokozati rendszerek a polgári magyar állam rendvédelmében.

19 Loc.cit.

20 Loc.cit.

21 Loc.cit.

22 Loc.cit.

${ }^{23}$ CSIZMADIA. 169-175.p. + 183.p. + 457-463.p.

${ }^{24}$ BORBÉLY - KAPY. II.köt. op.cit. 518-519.p.

${ }^{25}$ PARÁDI: A magyar rendvédelem személyi állományának szociális viszonyai 1867-1945.

${ }^{26}$ PARÁDI: A magyar állam határörizete 1920-1941. 73-75.p.

${ }^{27}$ A kényszertoborzás irányelveit — az országmozgósítási elgondolás részeként — a Legfelsőbb Honvédelmi Tanács titkárság a dolgozta ki.

VARGYAI. 29.p.

${ }^{28}$ PARÁDI: Nemzeti határörizetünk polgári szakasza.

${ }^{29} 6$ 200/1921. (VIII. 25.) ME.r. ; 114 440/1921. (VIII. 25.) PM.r.

30 1920. X. 4-én nyújtottak be előterjesztést a minisztertanács számára a hadihajózás folyamrendészetté történő átszervezéséről. A minisztertanács az előterjesztést 1921. I. 3-án elfogadta. A Magyar Királyi Folyamőrséget pedig 1921. III. 1-ei hatállyal állították fel. A Magyar Királyi Folyamőrséget 1922-ben törvénnyel iktatták az állami szervezetek sorába. A törvényben foglaltak végrehajtásáról pedig miniszterelnöki rendelet gondoskodott.

1922/XIV.tc. ; 8 270/1923. (XI. 23.) ME.r.

${ }^{31}$ PARÁDI: A magyar állam határörizete 1920-1941. op.cit. 273.p.

${ }^{32}$ Loc.cit. 150-157.p.

${ }^{33}$ Loc.cit.76-78.p.

${ }^{34}$ Loc.cit.79-85.p.

35 Orosházán a 66, Marosvásárhelyen pedig a 69 Magyar Királyi Honvéd Határvadász ezredet hozták létre. A 66. ezred részt vett a délvidéki bevonulásban.

${ }^{36}$ PARÁDI: A magyar állam határörizete 1920-1941. op.cit. 235.p.

${ }^{37}$ Loc.cit.

${ }^{38}$ RAFFAY

${ }^{39}$ DOMBRÁDY - TÓTH. 51-76.p.

${ }^{40}$ PARÁDI: A magyar határőrizet tere a kiegyezéstől a második világháborúig.

${ }^{41}$ Idem: A két világháború közötti Magyar Királyság rendvédelme.

${ }^{42} \mathrm{Idem}$ : A magyar rendvédelem története. 101-135.p.

435 047/1919. (X. 1.) ME.r. op.cit.

${ }^{44}$ 2300/1944. (VI. 21) ME.r. 


\section{Jegyzetekben alkalmazott röviditések:}

\section{MONOGRÁFIÁK, KISMONOGRÁFIÁK ÉS HASONLÓ JELLEGÜ KÖTETEK}

BORBÉLY - KAPY

BENCZÚR - CSONKARÉTY

CSIZMADIA

DOMBRÁDY — TÓTH

PARÁDI: A magyar rendvédelem története.

RAFFAY

REKTOR

VARGYAI

VÉCSEY

\section{TANULMÁNYOK}

PARÁDI József: A magyar határőrizet tere a kiegyezéstől a második világháborúig.

PARÁDI: A magyar rendvédelem személyi állományának szociális viszonyai 1867-1945.

PARÁDI: A két világháború közötti Magyar Királyság rendvédelme.

PARÁDi: Az egységes állami fizetési rendszer és a szakterületi rendfokozati rendszerek a polgári magyar állam rendvédelmében.

PARÁDI: Nemzeti határörizetünk polgári szakasza.

ZEIDLER
BORBÉLY Zoltán - KAPY Rezső (szerk.): A 60 éves magyar rendörség 1881-1941. Budapest, 1942, Halász Irodalmi és Könyvkiadó Vállalat. 594 p.

- BENCZÚR László - CsONKARÉTI Károly: Haditengerészet és folyamőrök a Dunán. A Császári (és) Királyi Haditengerészet dunai flottillájától a Magyar Királyi Honvéd Folyamerőkig 1870-1945. Budapest, 1991, Zrínyi. 291 p. HU-ISBN 9633271533.

- Csizmadia Andor: A magyar közigazgatás fejlödése a XVIII. századtól a tanácsrendszer létrejöttéig. Budapest, 1976, Akadémia Kiadó. 560 p. HUISBN 9630507137.

- Dombrády Lóránd - Tóth Sándor: A Magyar Királyi Honvédség 19191945. Budapest, 1987, Zrínyi. 461 p. HU-ISBN 963326359 X.

PARÁDI József et. al. (szerk.): A magyar rendvédelem története. Budapest, 1996², Osiris. 367 p. HU-ISBN 9630479583.

RAFFAY Ernő: Trianon titkai, avagy hogyan bántak el országunkkal. Budapest, 1990, Tornádó Domenio Kft. 191 p. HU-ISBN 9630276399.

- Rektor Béla: A Magyar Királyi Csendörség oknyomozó története. Cleveland, Ohio, USA, 1980, Árpád Könyvkiadó Vállalat. 552 p. USA-ISBN 0934214018 .

- VArgyai Gyula: A hadsereg politikai funkciói Magyarországon a harmincas években. Budapest, 1983, Akadémia Kiadó. 190 p. HU-ISBN 963 0530856.

- VÉCSEY Leó (szerk.): A 40 éves budapesti detektív testület jubiláris albuma 1886-1926. Budapest, 1927, A Magyar Királyi Államrendőrség Detektívtestületének Nyugdíjpótló és Segélyező Egyesülete. 320 p.

PARÁDI József: A magyar határörizet tere a kiegyezéstől a második világháborúig. Rendvédelem-történeti Füzetek (Acta Historiae Praesidii Ordinis), XII. évf. (2007) 15.sz. 125-138.p. HU-ISSN 1216-6774. A tanulmány korábbi változata 2005. augusztus 27-én a szlovéniai Lendván hangzott el a Hajnal István kör által szervezett tudományos konferencián. A publikált tanulmány az előadás javított, bővített és átdolgozott változata.

PARÁDI József: A magyar rendvédelem személyi állományának szociális viszonyai 1867-1945. Rendvédelem-történeti Füzetek (Acta Historiae Praesidii Ordinis), XV.évf. (2008) 17.sz. 57-64.p. HU-ISSN 1216-6774. A tanulmány korábbi változata 2003. november 11-én Budapesten hangzott el a Szemere Bertalan Magyar Rendvédelem-történeti Tudományos Társaság által szervezett rendvédelem-történeti tudományos konferenciasorozatnak a „, $A$ rendvédelem humán viszonyai" címü XVII. konferenciáján. A publikált tanulmány az elöadás javított, bővített és átdolgozott változata.

PARÁDI József: A két világháború közötti Magyar Királyság rendvédelme. Rendvédelem-történeti Füzetek (Acta Historiae Praesidii Ordinis), XVIII. évf. (2010) 21. sz. 85-100.p. HU-ISSN 1216-6774. A tanulmány korábbi változata 2007. október 5.-én Budapesten hangzott el a Szemere Bertalan Magyar Rendvédelem-történeti Tudományos Társaság által szervezett rendvédelem-történeti tudományos konferenciasorozatnak „A magyar rendvédelem fejlödése a XIX-XX. században” címü XXI. konferenciáján. A publikált tanulmány az előadás javított, bővített és átdolgozott változata.

PARÁDI József: Az egységes állami fizetési rendszer és a szakterületi rendfokozati rendszerek a polgári magyar állam rendvédelmében. Rendvédelemtörténeti Füzetek (Acta Historiae Praesidii Ordinis), XXII.évf. (2012) 26.sz. 105-119.p. HU-ISSN 1216-6774.

PARÁDI József: Nemzeti határőrizetünk polgári szakasza. Rendvédelemtörténeti Füzetek (Acta Historiae Praesidii Ordinis), XXIII.évf. (2013) $27-$ 28-29-30.sz. 141-154.p. HU-ISSN 1216-6774.

- ZEIDLER Sándor: A magyar rendőri rangok fejlődéstörténete a kiegyezéstől az ezredfordulóig. Rendvédelem-történeti Füzetek (Acta Historiae Praesidii Ordinis), XIV.évf. (2008) 17.sz. 116-137.p. HU-ISSN 1216-6774. A tanulmány korábbi változata 2003. november 11-én, Budapesten hangzott el a Szemere Bertalan Magyar Rendvédelem-történeti Tudományos Társaság által szervezett rendvédelem-történeti tudományos konferenciasorozatnak „A rendvédelem humán viszonyai" címü XVII. konferenciáján. A publikált tanulmány az elöadás javított, bővített és átdolgozott változata. 


\section{KÉZIRATOK}

PARÁDI József: A magyar állam határörizete 1920-1941.

PARÁDI József: A magyar állam határörizete 1920-1941. Kandidátusi

\section{JOGSZABÁLYOK}

1922/XIV.tc.

5 047/1919. (X. 1.) ME.r.

1053/1920. (II.12.) ME.r

6 200/1921. (VIII. 25.) ME.r.

114 440/1921. (VIII. 25.) PM.r.

8 270/1923. (XI. 23.) ME.r.

6 500/1931. (XI. 30.) ME.r.

2300/1944. (VI. 21) ME.r. értekezés (MTA-TMB). Kézirat. Budapest, 1990.

— 1922/XIV.tc. a Magyar Királyi Folyamőrség szervezéséröl, létszámának, kiegészítési módjának és felfegyverkezésének megállapításáról.

- 5 047/1919. (X. 1.) ME.r. a rendőrség államosításáról. Magyarországi Rendeletek Tára, LIII.évf. (1919) I.füzet. 752-767.p.

- 1053/1920. (II.12.) ME.r. a folyamrendészet gyakorlásáról. Magyarországi rendeletek Tára LV. (1921) I. füzet. 36-37.p.

- 6 200/1921. (VIII. 25.) ME.r. a vámőrség létesítéséröl. Magyarországi Rendeletek Tára, LV.évf. (1922) I.füzet. 223-232.p.

- $\quad 114$ 440/1921. (VIII. 25.) PM.r. a Magyar Királyi Vámőrség létesítéséről szóló 6.200/1921. M. E. számú kormányrendelet végrehajtásáról. MagyarországiRendeletek Tára, LV.évf. (1922) I.füzet. 1594-1623.p.

- 8 270/1923. (XI. 23.) ME.r. a folyamrendészet gyakorlásáról és a Magyar Királyi Folyamőrség szervezéséről, létszáma kiegészítési módjainak és felfegyverzésének megállapításáról szóló 1922: XIV. tc. végrehajtásáról. Magyarországi Rendeletek Tára, LVII.évf. (1924) I.füzet. 335-340.p.

- 6 500/1931. (XI. 30.) ME.r. a rendőrség szervezeti változásairól. Magyarországi Rendeletek Tára, LXV.évf. (1931) XII.füzet. 1533-1534.p.

— 2300/1944. (VI. 21) ME.r. a Magyar Királyi Rendőrség átszervezéséről. Magyarországi Rendeletek Tára, LXXVII.évf. (1944) 1063.p.

Mellékletek jegyzéke:

I.sz. melléklet

A Magyar Királyi Államrendőrség főkapitányságai 1921-1931.

II.sz. melléklet

A Magyar Királyi Rendőrség budapesti főkapitányságának szervezeti felépítése 1944-ben.

III.sz. melléklet

A Magyar Királyi Rendőrség személyi állománycsoportjai.

IV.sz. melléklet

Lakbérővezeti táblázat.

V.sz. melléklet

Nyugdíjtáblázat.

VI.sz. melléklet

A Magyar Királyi Vámőrség szervezeti felépítése 1931-ben.

VII.sz. melléklet

A Magyar Királyi Határőrség szervezeti felépítése.

VIII.sz. melléklet

A Magyar Királyi Honvéd Határvadászok határszolgálatos erőinek szervezeti felépítése. 
A Magyar Királyi Államrendörség fökapitányságai 1921-1931.

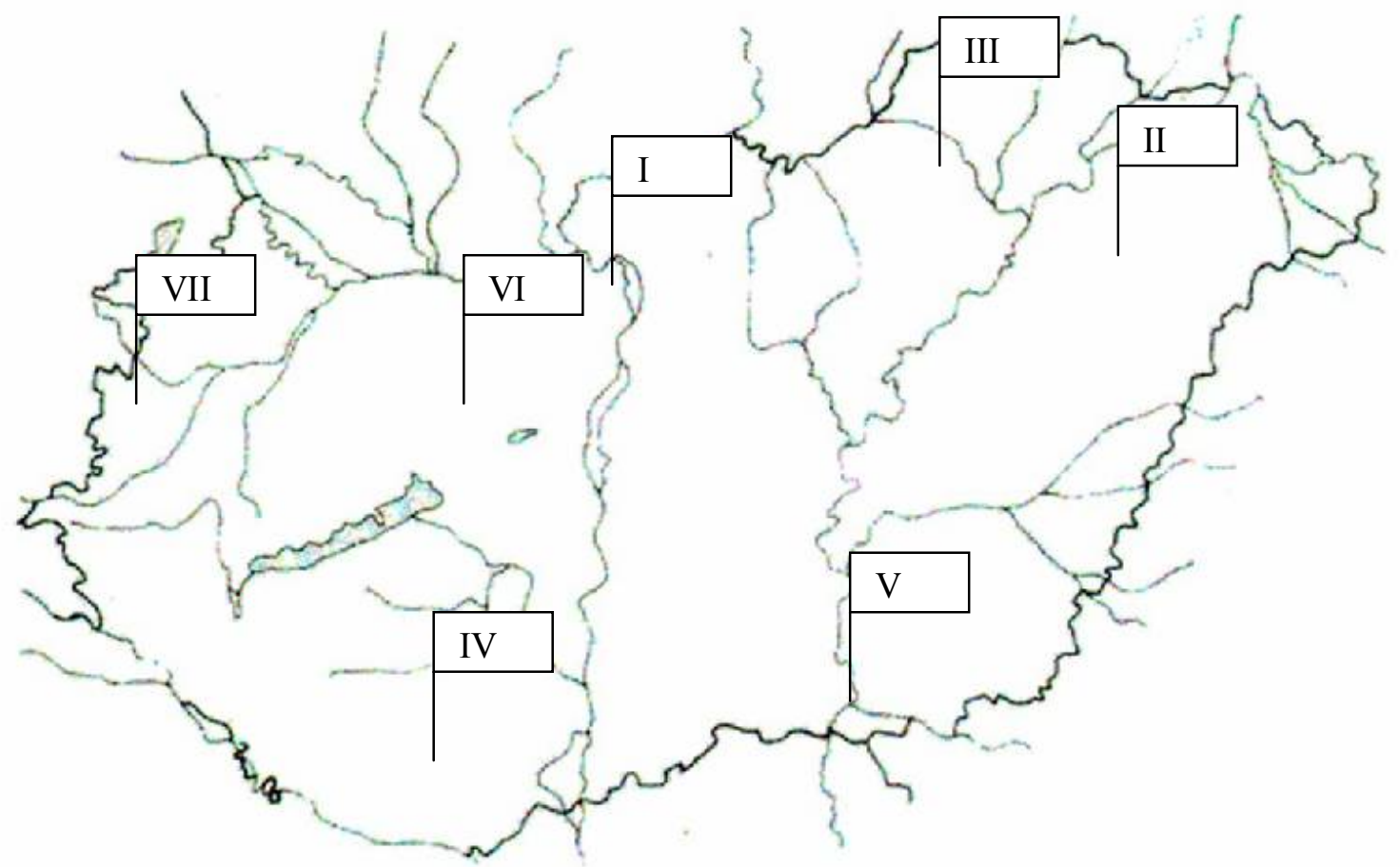

Jelmagyarázat:

Rendőr-főkapitányság

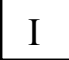

Rendőr-főkapitánysági székhelyek

$\begin{array}{ll}\text { I } & =\text { Budapest } \\ \text { II } & =\text { Debrecen } \\ \text { III } & =\text { Miskolc } \\ \text { IV } & =\text { Pécs } \\ \text { V } & =\text { Szeged } \\ \text { VI } & =\text { Székesfehérvár } \\ \text { VII } & =\text { Szombathely }\end{array}$

Forrás ! BORBÉLY Zoltán - KAPY Rezső (szerk.): A 60 éves magyar rendőrség 1881-1941. 395.p. Budapest, 1942, Halász Irodalmi és Könyvkiadó Vállalat. 594 p. 


\begin{tabular}{|c|c|c|c|c|c|c|c|c|c|c|c|c|c|c|}
\hline 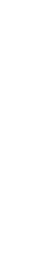 & $\underline{x}$ & $x$ & $\bar{x}$ & $\leqq$ & $\leqq$ & $\leq$ & $<$ & $\bar{\varepsilon}$ & $\mathbf{E}$ & $=$ & & & 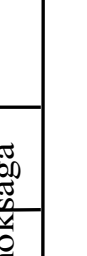 & \\
\hline 点 & 胳 & 岕 & 9 & 芯 & $\begin{array}{l}\overrightarrow{\overrightarrow{\vec{p}}} \\
\mathbf{N}\end{array}$ & 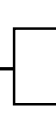 & 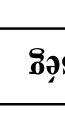 & 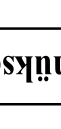 & 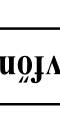 & $\begin{array}{l}\text { ज्ञ } \\
\bar{g} \\
g\end{array}$ & & N㴧点 & & \\
\hline 崩 & 9 & 竞 & $\begin{array}{l}\text { E } \\
\text { L } \\
\text { t. }\end{array}$ & \begin{tabular}{|l}
$\overrightarrow{\mathbf{g}}$ \\
$\vec{\omega}$
\end{tabular} & $\mid \begin{array}{l}\vec{w} \\
\vec{p} \\
\vec{\sigma}\end{array}$ & $\begin{array}{l}\overrightarrow{\mathbf{D}} \\
\vdots \\
\vdots\end{array}$ & $\overrightarrow{\mathrm{Z}}$ & ָ̃ & $\begin{array}{c}\mathbf{N} \\
\overline{\underline{p}} \\
\vdots \\
\vdots\end{array}$ & 苟 & & & & \\
\hline 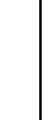 & $\left|\begin{array}{l}\mathbf{w} \\
\vdots \\
a\end{array}\right|$ & W & on & 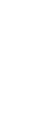 & 咅 & 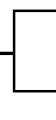 & $\begin{array}{l}\vec{E} \\
\vec{E}\end{array}$ & 悹 & $\begin{array}{c}\overrightarrow{\mathrm{D}} \\
\mathbf{N} \\
\mathbf{t}\end{array}$ & & ? & & $\begin{array}{l}0 \\
0 \\
= \\
=\end{array}$ & \\
\hline $\begin{array}{l}\text { 湈 } \\
\text { g }\end{array}$ & : & 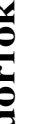 & 窇 & 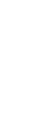 & $\begin{array}{l}\overrightarrow{\hat{N}} \\
\vec{\omega}\end{array}$ & $\begin{array}{l}\vec{E} \\
E\end{array}$ & $\begin{array}{l}\overrightarrow{\vec{\omega}} \\
\mathbf{s} \\
\mathbf{N}\end{array}$ & $\begin{array}{c}\vec{W} \\
\underline{w} \\
\Delta\end{array}$ & $\begin{array}{l}\overrightarrow{\mathbf{t}} \\
\overrightarrow{\mathbf{E}}\end{array}$ & $\begin{array}{l}\text { W్ } \\
\text { ڤ్ }\end{array}$ & $\begin{array}{l}\infty \\
= \\
=1\end{array}$ & & $\begin{array}{l}0 \\
= \\
N \\
0\end{array}$ & $F$ \\
\hline$\stackrel{\text { p. }}{\Xi}$ & $\mid \begin{array}{l}\mathbf{b} \\
\vdots \\
\mathbf{b} \\
\mathbf{w}\end{array}$ & 志 & $\begin{array}{l}2 \\
0 \\
0\end{array}$ & $\stackrel{Z}{N}$ & $\frac{f}{a}$ & $\overrightarrow{\overrightarrow{\vec{t}}}$ & $\begin{array}{l}\overrightarrow{\tilde{w}} \\
\underline{\underline{w}} \\
\underline{\underline{s}}\end{array}$ & 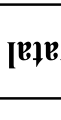 & $\begin{array}{l}\vec{s} \\
\vec{v} \\
\vec{v}\end{array}$ & 弍 & $\begin{array}{l}\text { D. } \\
0.1 \\
z\end{array}$ & & & \\
\hline 点 & $\mid \begin{array}{l}2 \\
\vdots \\
\vdots \\
\vdots\end{array}$ & ة: & : & 鸾 & \begin{tabular}{|l|}
$\overrightarrow{\mathbf{b}}$ \\
$\overrightarrow{\underline{\omega}}$
\end{tabular} & $\begin{array}{l}\overrightarrow{\tilde{N}} \\
\underline{\underline{E}}\end{array}$ & $\mid \begin{array}{l}\overrightarrow{\vec{E}} \\
\overrightarrow{\underline{G}}\end{array}$ & $\mid \begin{array}{l}\vec{\nabla} \\
\vec{w} \\
\overrightarrow{\mathbf{v}}\end{array}$ & \begin{tabular}{|l|}
$\overrightarrow{\vec{n}}$ \\
$\overrightarrow{\mathbf{N}}$ \\
\end{tabular} & & $\begin{array}{l}0.1 \\
x \\
0.1\end{array}$ & & $\overline{\mathbf{z}}$ & $F$ \\
\hline 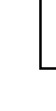 & 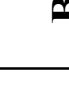 & 离 & 索 & 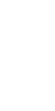 & N & 㝘 & $\begin{array}{l}\overrightarrow{\overrightarrow{\vec{w}}} \\
\underline{\underline{w}}\end{array}$ & $\begin{array}{l}\overrightarrow{\vec{\omega}} \\
\stackrel{\overrightarrow{0}}{\mathbf{t}}\end{array}$ & 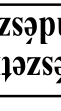 & & $\begin{array}{l}5 \\
0 \\
0 \\
N\end{array}$ & & $\begin{array}{l}+ \\
0 \\
7\end{array}$ & 0 \\
\hline 崫 & 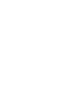 & 岕 & 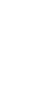 & | & $\begin{array}{l}\mathbf{E} \\
\text { g }\end{array}$ & $\begin{array}{l}\overrightarrow{\overrightarrow{\vec{N}}} \\
\underline{\underline{\omega}}\end{array}$ & $\begin{array}{l}\overrightarrow{\mathbf{q}} \\
\overrightarrow{\mathbf{v}}\end{array}$ & $\begin{array}{l}\overrightarrow{\vec{\xi}} \\
\overrightarrow{\underline{G}}\end{array}$ & $\begin{array}{l}\overrightarrow{\mathrm{p}} \\
\mathbf{y}\end{array}$ & & | & & $\begin{array}{l}+ \\
0 \\
N\end{array}$ & 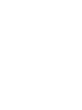 \\
\hline ్ָ & 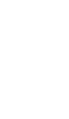 & $\begin{array}{l}\mathbf{w} \\
w \\
N\end{array}$ & 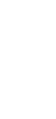 & W & : & $\stackrel{\varpi}{\breve{~}}$ & $\begin{array}{l}0 \\
\vdots \\
\vdots \\
\vdots\end{array}$ & $\overrightarrow{\overrightarrow{\vec{t}}}$ & \begin{tabular}{|l|}
$\overrightarrow{\hat{N}}$ \\
$\vec{\Delta}$ \\
$\mathbf{b}$
\end{tabular} & & |l & & $\begin{array}{l}= \\
0\end{array}$ & : \\
\hline 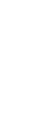 & $\mid \begin{array}{l}\mathbf{b} \\
0 \\
\mathbf{b} \\
\mathbf{w}\end{array}$ & $\begin{array}{l}\mathbf{5} \\
9 \\
9\end{array}$ & 常 & 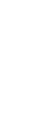 & 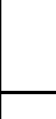 & D̆ & $\begin{array}{l}\vec{b} \\
\vec{\Xi} \\
\Xi\end{array}$ & $\begin{array}{l}\overrightarrow{\underline{N}} \\
\stackrel{\vec{\omega}}{\Delta}\end{array}$ & $\begin{array}{l}\overrightarrow{\underline{\omega}} \\
\stackrel{\vec{\omega}}{\vec{\Delta}}\end{array}$ & $\begin{array}{l}\overrightarrow{\vec{N}} \\
\text { du }\end{array}$ & $=$ & 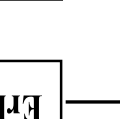 & $\begin{array}{l}5 \\
0 \\
2\end{array}$ & \\
\hline$\stackrel{N}{\tilde{L}}$ & $\tilde{N}$ & $\begin{array}{l}\mathbf{n} \\
\mathbf{5} \\
\mathbf{3}\end{array}$ & 出 & 点 & 㟧 & تั & 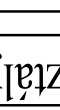 & 总 & 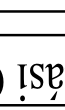 & 产 & & 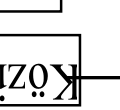 & 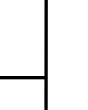 & $\omega$ \\
\hline 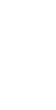 & $z$ & & $\begin{array}{l}\mathbf{N} \\
\mathbf{Z}\end{array}$ & & : & $\begin{array}{l}0 \\
\square \\
\end{array}$ & 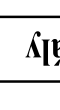 & 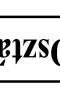 & $\mid$\begin{tabular}{|c|}
$\overrightarrow{0}$ \\
$\dot{\omega}$ \\
\end{tabular} & 矛 & & w齿活 & & \\
\hline
\end{tabular}




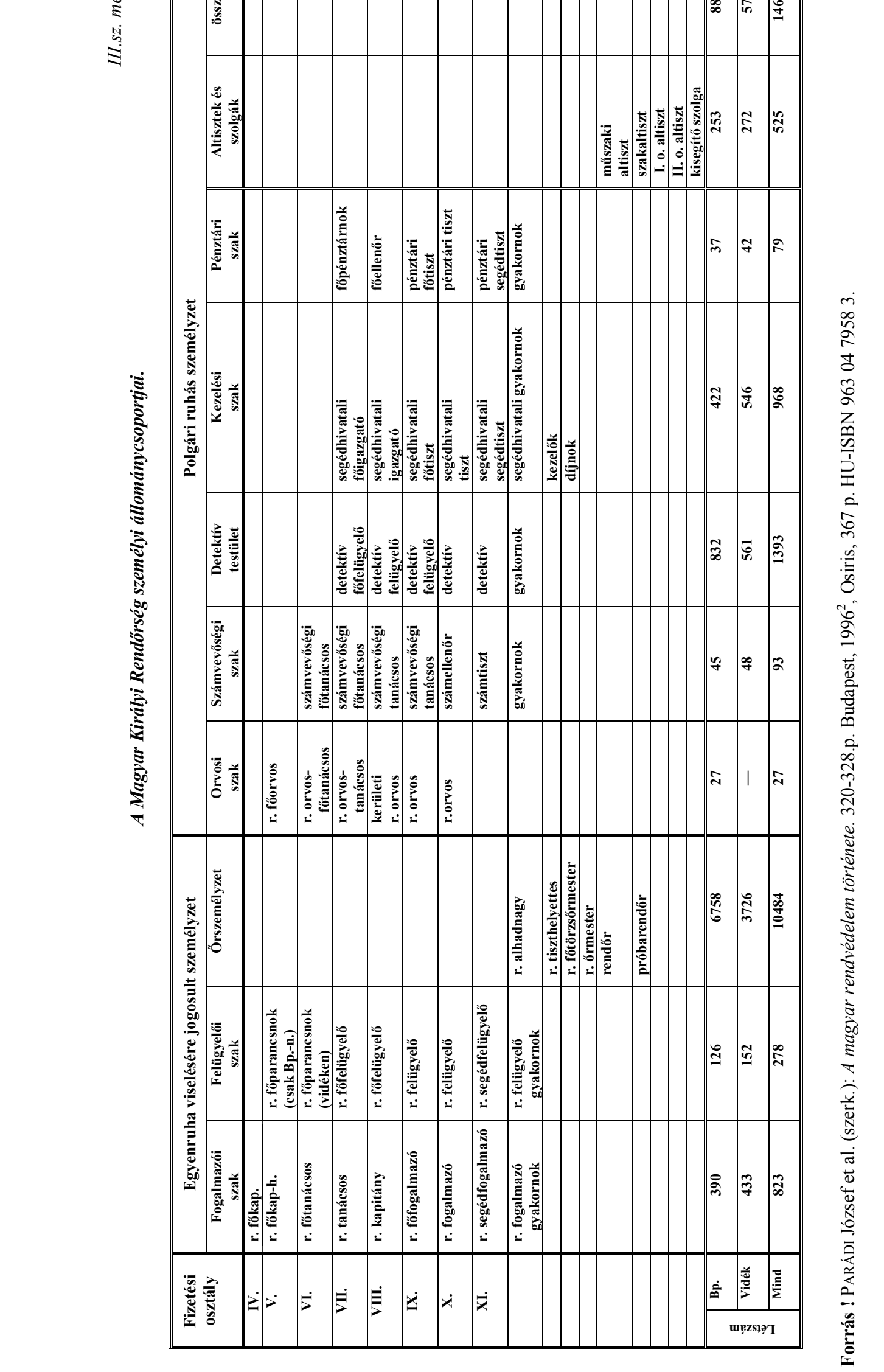

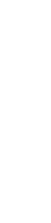




\section{VAMŐR FÖPARANGSNOKSÁG}

Forrás ! PARÁd József et al. (szerk.): A magyar rendvédelem története. Budapest, 1996², Osiris, 367 p. HU-ISBN 9630479583.

A Magyar Királyi Határőrség szervezeti felépítése.

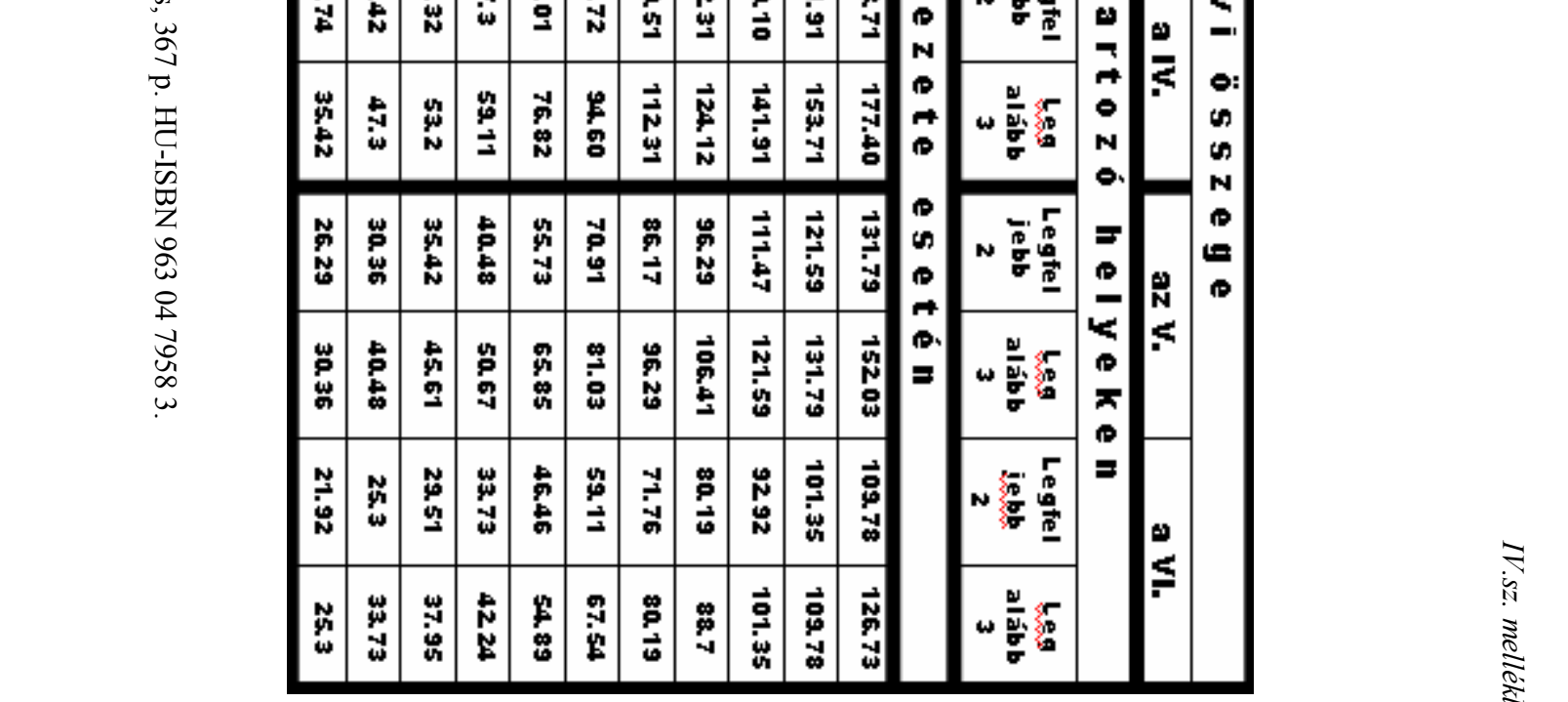

Forrás ! PARÁDI József et al. (szerk.): A magyar rendvédelem története. Budapest, 1996², Osiris, 367 p. HU-ISBN 9630479583. 
A Magyar Királyi Honvéd Határvadászok

VIII.sz. melléklet határszolgálatos erőinek szervezeti felépítése.

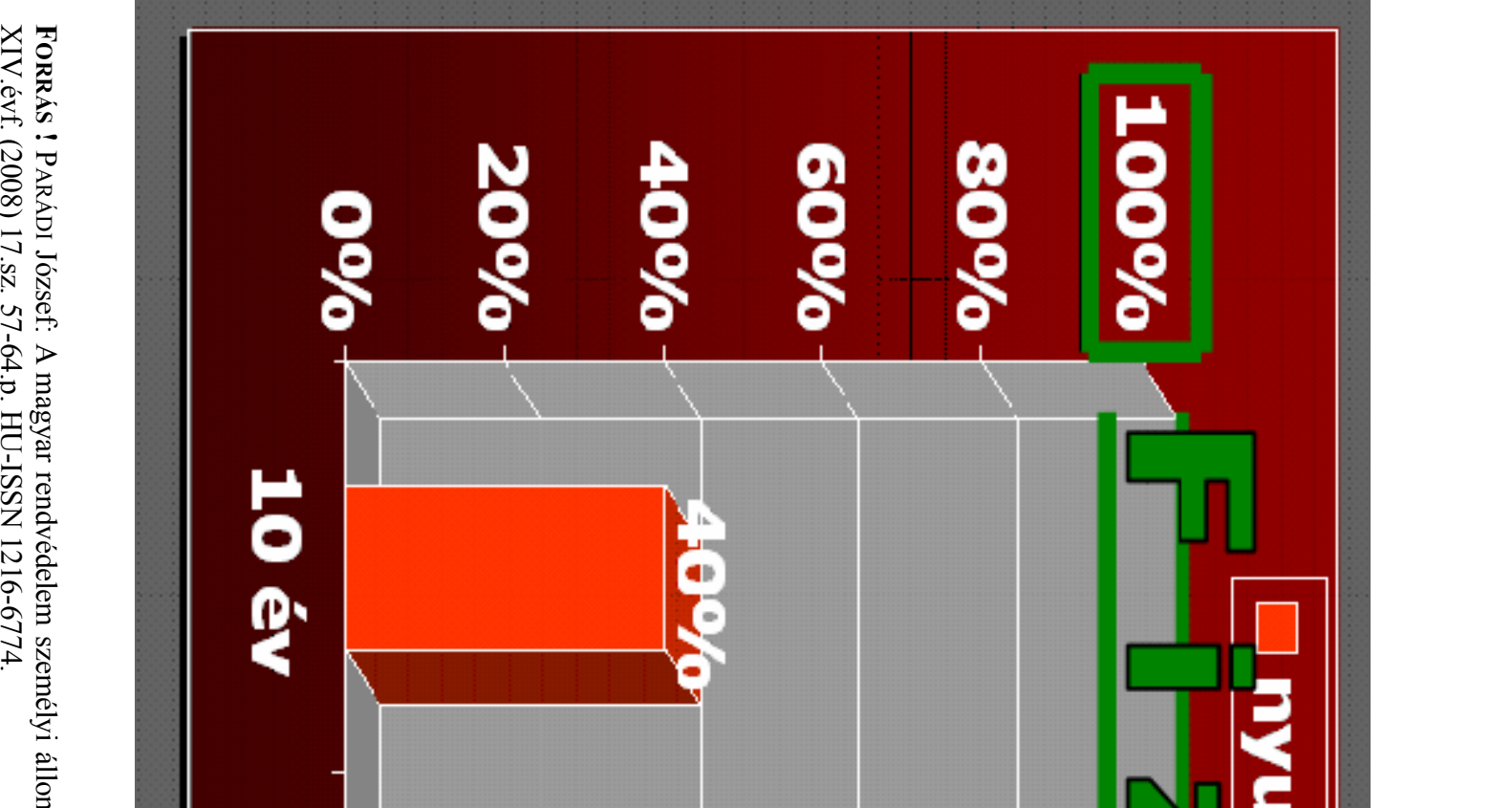

Forrás ! PARÁDI József et al. (szerk.): A magyar rendvédelem története. Budapest, 1996², Osiris, 367 p. HU-ISBN 9630479583. 
A Magyar Királyi Honvéd Határvadászok

VIII.sz. melléklet határszolgálatos erőinek szervezeti felépítése.

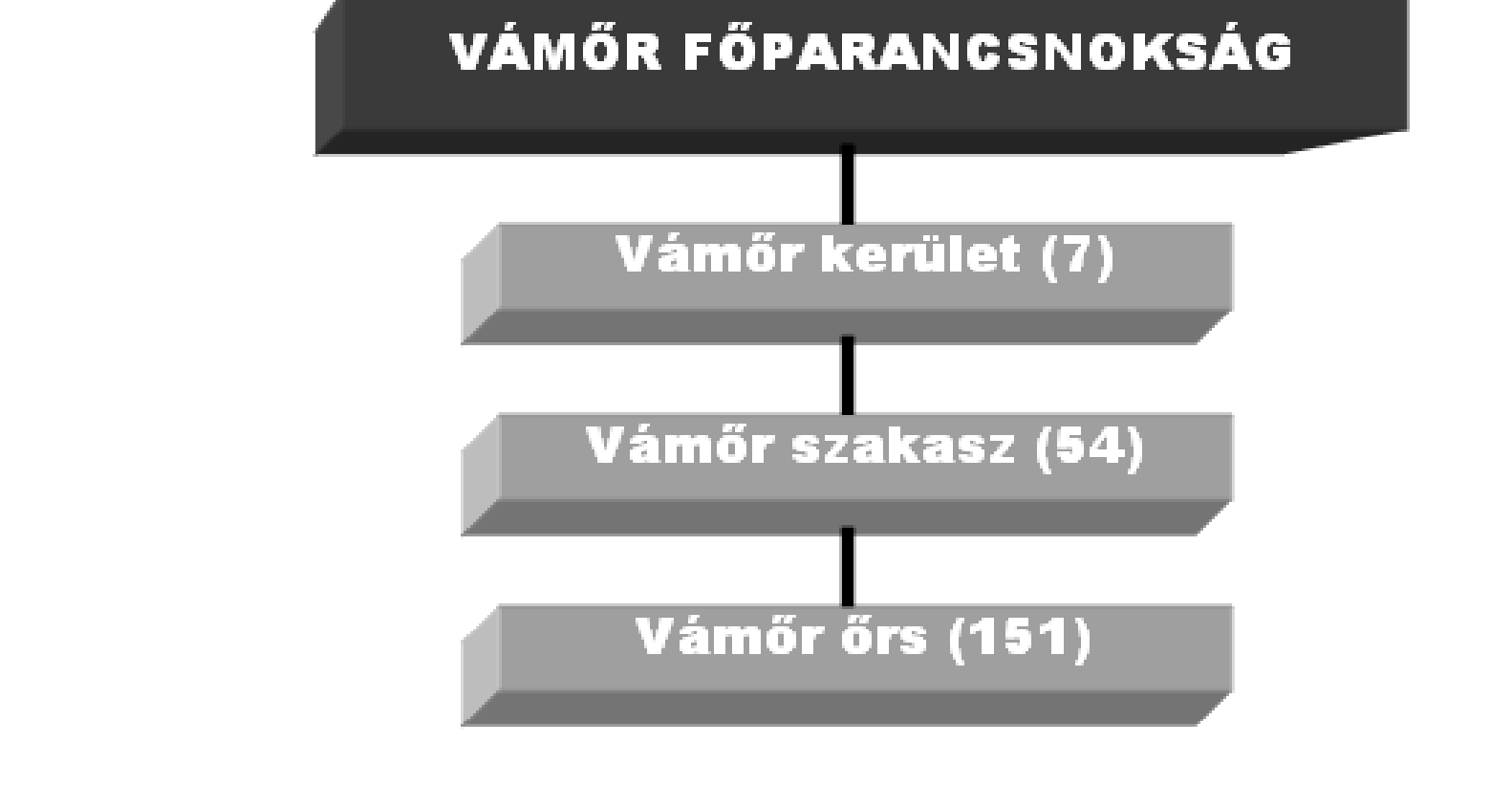

Forrás ! PARÁDI József et al. (szerk.): A magyar rendvédelem története. Budapest, 1996², Osiris, 367 p. HU-ISBN 9630479583. 
A Magyar Királyi Honvéd Határvadászok

VIII.sz. melléklet határszolgálatos erőinek szervezeti felépítése.

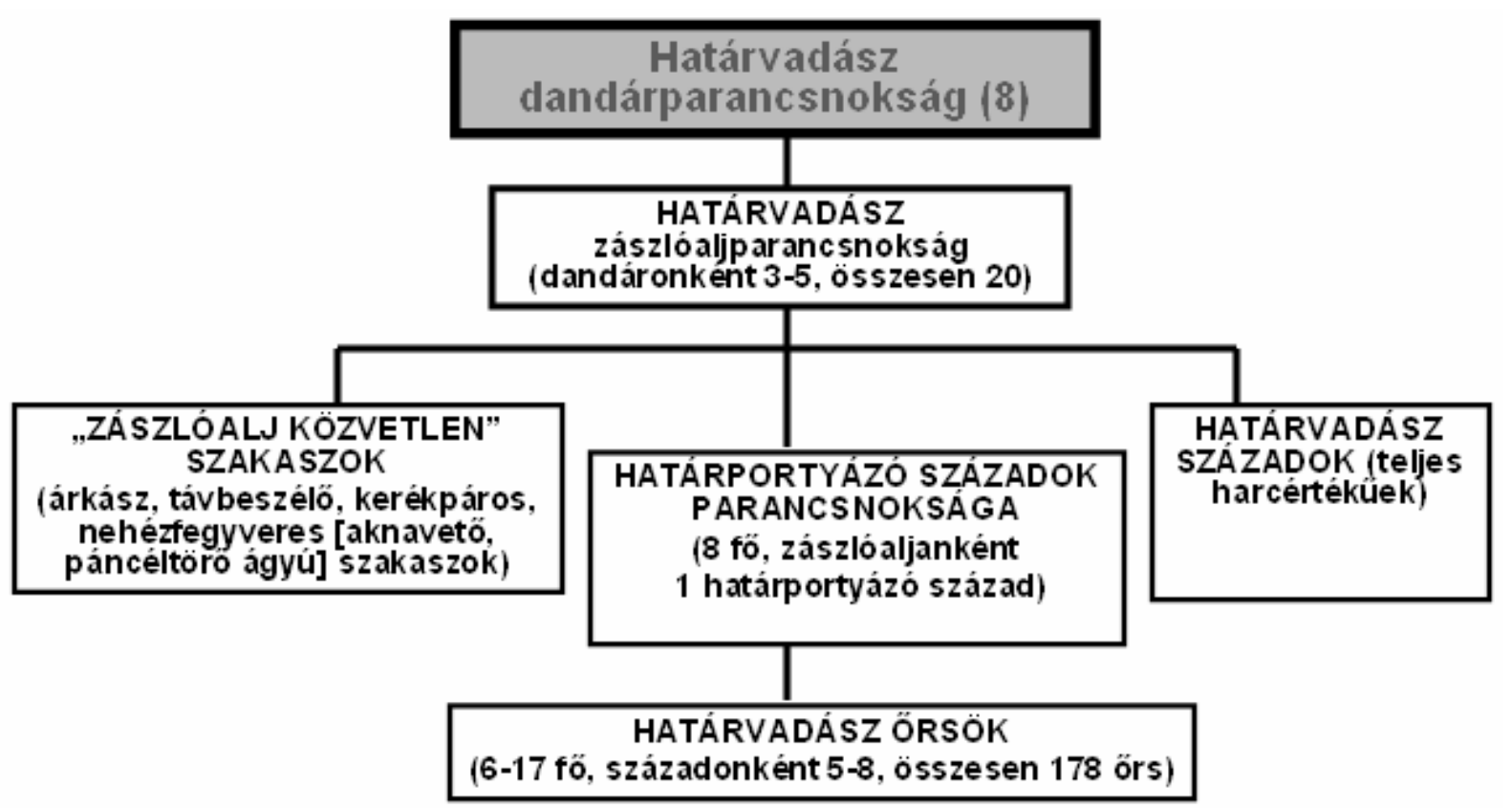

Forrás ! PARÁDI József et al. (szerk.): A magyar rendvédelem története. Budapest, 1996², Osiris, 367 p. HU-ISBN 9630479583. 